Article

\title{
Succession of Mite Assemblages (Acari, Mesostigmata) during Decomposition of Tree Leaves in Forest Stands Growing on Reclaimed Post-Mining Spoil Heap and Adjacent Forest Habitats
}

\author{
Cezary K. Urbanowski ${ }^{1}$, Paweł Horodecki ${ }^{2}{ }^{\circledR}$, Jacek Kamczyc ${ }^{1}$, Maciej Skorupski ${ }^{1}{ }^{1}$ and \\ Andrzej M. Jagodziński 1,2,*iD \\ 1 Department of Game Management and Forest Protection, Faculty of Forestry, Poznań University of Life \\ Sciences, Wojska Polskiego 71C, 60-625 Poznań, Poland; cezar.u93@gmail.com (C.K.U.); \\ jacek.kamczyc@gmail.com (J.K.); maskorup@up.poznan.pl (M.S.) \\ 2 Institute of Dendrology, Polish Academy of Sciences, Parkowa 5, 62-035 Kórnik, Poland; \\ pawelhorodecki@gmail.com \\ * Correspondence: amj@man.poznan.pl; Tel.: +48-61-8170033
}

Received: 11 October 2018; Accepted: 16 November 2018; Published: 19 November 2018

\begin{abstract}
Mites significantly contribute, prevalently by vertical movement, to mixing of the organic layer with the mineral soil, thus they may be important in renewing soils. Our aim was to analyze the changes in abundance and species richness of mesostigmatid assemblages on decomposing leaves of Alnus glutinosa (L.) Gaertn., Betula pendula Roth, Pinus sylvestris L. and Quercus robur L. in pine and birch stands growing on a reclaimed spoil heap and adjacent forests. In December 2013, 1024 litterbags (mesh size $=1 \mathrm{~mm}$ ) containing leaf litter of broadleaved and coniferous trees (mean initial dry weight per sample $=5.789 \mathrm{~g}$ ) were laid out in the same number and kind in each of the two sites. Mites were extracted from litterbags which were collected every 3-6 months for 3 years. In total, 6466 mites were identified in 59 taxa. Total abundance was higher on forest habitats ( 5174 specimens) compared to the spoil (1292), and in birch compared to pine stands, both in forest (3345, 1829, respectively) and spoil habitats $(981,311)$. Throughout the experiment, mites were most abundant on oak litter samples $(2063$ specimens), while the remaining litter types had similar abundances (1455-1482). At the beginning of the experiment (3-6 months) mite abundance was very low, but was higher on forest habitats. The highest abundance was found after 9 months-144 specimens in pine stands on the spoil heap and 685 in birch stands on forest habitats. During the study, 49 taxa were found on forest and 29 on heap habitats. In birch stands, 37 and 22 taxa were found, whereas in pine 30 and 21, on forest and heap, respectively. The most frequent species on the heap were Amblyseius tubae Karg, Asca bicornis Canestrini et Fanzago, and Asca aphidioides Linneaeus, whereas in forest habitat-Zercon peltatus C.L. Koch, Veigaia nemorensis C.L. Koch, and Trachytes aegrota C.L. Koch. Habitat conditions, tree species and litter type significantly determined the mesostigmatid species composition, richness and abundance. By selection of dominant tree species during afforestation, it is possible to significantly affect the soil fauna composition, and thus indirectly the rate of decomposition.
\end{abstract}

Keywords: post-mining site; Gamasida; litterbags; soil mesofauna; colonization; afforestation; soil reclamation; leaf degradation; organic matter

\section{Introduction}

The breakdown of dead organic matter, i.e., decomposition, is the basic biogeochemical process, consisting of the physico-chemical and biological degradation of organic matter, which results in the 
circulation of macro- and microelements in ecological systems [1-3]. Despite the key importance of this process for the functioning of life on the Earth, our knowledge of it is still fragmented [4], particularly with regard to the course of decomposition in disturbed ecological systems [1,4].

The soil, more precisely soil substrate, on post-mining sites (e.g., external dumps), differs significantly from forest soils, in structural, physical, chemical and biological parameters [5]. The characteristic features of soils such as structure of the soil profile, appropriate water and air conditions [6], amount of organic matter [7] and high microbiological activity are absent [5]. However, thanks to the specific conditions that arose as a result of human activity on degraded sites subjected to reclamation, these areas may be potential habitats for many species of animals [8-11], including mites [12-14]. Colonization of post-industrial areas by invertebrates, such as mites, undoubtedly supports soil-forming processes, but the scale of this process is still insufficiently recognized [14].

One of the taxonomic groups that exists in the top layer of soil and significantly contributes to circulation of organic matter in various ecological systems are mites (Acari) [15]. Their presence is observed in all soil layers; however, distinct differences in species composition of zoocenoses which they create were noticed, along with changes in depth of the soil profile $[16,17]$. This is conditioned on behavioural traits of soil mites such as methods of feeding or types of movements [18]. Although the soil mites are not always considered to mix the soil mechanically, their vertical movement in the soil may contribute to the mixing of the top organic layer with the mineral soil substrate $[17,19]$.

One of the rich species groups among acarofauna is mesostigmatid mites (Mesostigmata $=$ Gamasida) [20], among which can be distinguished parasitic [21] or free-living forms [22]. Within the order Mesostigmata, most mite species are predators, such as the suborder Gamasina [23], with the exception of a few species from the families Rhodacaridae, Ameroseiidae and Aceosejidae [19]. Predatory gamasid mites feed mainly on nematodes (Nematoda), Collembola, potworms (Enchytraeidae) and insect larvae (Insecta) [22], which contribute to the shredding of dead organic matter, thus affecting the rate of litter decomposition [3]. Vreeken-Buijs and Brussaard [24] proved that the decomposition rate was predator controlled. In general, mesostigmatid mites (predominantly as predators) do not directly affect soil processes, such as breakdown of dead organic matter, but they have real and direct influence on other soil organisms [19], e.g., fungivorous springtails [25] or herbivorous oribatid mites (Oribatida), which are the dominant mite group in the soil [22]. Due to their ecological and behavioural traits, gamasid acarofauna are located at the ends of trophic chains and are often used as a tool for bioindication or ecological monitoring of disturbed habitats [26].

Many aspects of how soil organisms influence the rate and course of ecological soil processes on industrial and post-industrial sites have been studied. However, a literature survey suggests that there are only a few papers on gamasid mite assemblages on disturbed and reclaimed mine habitats. For example, Koehler [27] and Koehler and Melecis [28] conducted their research on a rubble and debris dump. Their studies proved that specific climate conditions and successional changes of vegetation are correlated and significantly affect the structure, species composition and abundance of gamasid assemblages. Mesostigmatid mites have also been studied on a post-industrial power plant waste dump, as well as coal, zinc, lead or dolomitic dumps [29-31] or on a brown coal external spoil heap [32-34]. These investigations revealed that structure and species composition of mite assemblages is highly dependent on the habitat type and site in which they occur. For example, Madej and Skubała [30] and Piasta et al. [34] found significant differences in mite assemblages between degraded sites and surrounding forest stands. Moreover, it was found that the tree species composition of forest stands growing on reclaimed sites also significantly affected the number of mites and species composition [32].

The effects of the soil organisms that occur and their interactions on the breakdown of dead organic matter has been minimally examined. For instance, decomposition of leaves of 14 tree species was examined in relation to earthworms (Lumbricidae) [35-37] or other edaphic groups, e.g., nematodes, oribatids and predatory mites from the order Mesostigmata $[37,38]$ in a common 
garden experiment, where results have revealed that species richness and diversity of investigated soil fauna were significantly affected by the release rate and amount of micro- and macroelements, light availability in the understory or decomposition rate. Furthermore, Gergocs and Hufnagel [39] suggested that the quality of forest litter determined the density of microarthropods; however, Fujii and Takeda [3] obtained results which showed that litter quality is not a primary factor controlling the distribution of microarthropods. Also, the breakdown of litter in broadleaved and coniferous forests, as it relates to microbial activity and microarthropods, was studied by Gao et al. [40]. They revealed that addition of microorganisms to the degraded soil might accelerate the development of edaphic fauna and thus indirectly affect the leaf litter decomposition rate. Moreover, Kaneko and Salamanca [41], Riutta et al. [42], Slade and Riutta [43] and Frouz et al. [10] studied the correlation between decomposition, abundance and species composition of arthropods, and their influence and role in litter breakdown processes. Kaneko and Salamanca [41] found a positive correlation between mass loss of organic matter and microarthropod abundance in mixed litter samples, but a negative correlation in single-species litter. Results obtained by Riutta et al. [42], Slade and Riutta [43] and Frouz et al. [10] revealed positive and accelerating effects of soil macrofauna on the rate of litter decomposition, regardless of the moisture conditions [42], however, macrofauna did not significantly affect the rate of soil mineralization [10].

The decay of dead organic matter on post-industrial lands was also analyzed in a few studies (e.g., [7,44-46]), but studies linking litter decomposition and edaphic fauna, particularly on disturbed or degraded habitats, are still lacking. Only a few publications touch the problem of breakdown of dead organic matter in forest stands growing on post-industrial or degraded habitats in the context of soil organisms. The previous investigations concerned and examined the characteristics of microbial communities at initial habitats of volcanic [47] or post-mining soils [48]. For example, Frouz [8,9] and Dunger et al. [12] studied the relationships between soil organisms and breakdown processes of leaf litter on reclaimed and unreclaimed post-mining sites and they revealed that investigated soil fauna, the quality, distribution, abundance and composition of assemblages, significantly depends on site and decomposing litter features. Moreover, Frouz [8,9] have proved that macrofauna significantly affect the decomposition and removal of dead organic matter from the surface to the deeper mineral layer, but do not affect the mineralization processes.

Numerous research works which considered the soil fauna and litter decomposition lasted for one year $[8,9,15,42,43]$. However, some studies lasted only 30 weeks [48], others up to 2 years [12,36,41]. There are only a few studies that lasted for a longer period. For example, Fujii and Takeda [3] studied litter decomposition in relation to microarthropods for 3 years, nevertheless, their work was based on 7 collection periods at uneven time intervals ( 3 and 6 months). However, most of the experiments published were based on collection periods at two [15] or three [42,43] month intervals. Among the published studies, there were few that used intervals lasting less than two months or weeks $[12,48]$. In some publications, such as Kaneko and Salamanca [41], Frouz [8,9], Riutta et al. [42] or Fujii and Takeda [3] there were intervals of one year, which may not fully show the connections between soil fauna and ongoing processes, such as succession of organisms.

For a better understanding of predatory mite ecology and biology, the aim of our research was to analyze the rate of succession of mesostigmatid mite assemblages on the decomposing leaves of alder (Alnus glutinosa (L.) Gaertn.), birch (Betula pendula Roth), pine (Pinus sylvestris L.) and oak (Quercus robur $\mathrm{L}$.) in pine and birch stands growing in different habitat conditions-on reclaimed post-mining sites and forest. All the tree species studied are widely used in reclamation of post-mining habitats and they are differentiated in their ecological features. We hypothesized that (1) habitat type (spoil heap vs. forest habitat) and stand type (birch and pine) would significantly affect the abundance and species richness of mite assemblages on decaying litter. We assumed that abundance as well as species richness would be lower on spoil heap areas compared to adjacent forest habitats, (2) in both P. sylvestris and B. pendula stands. Moreover, we hypothesized that (3) mite assemblages would differ significantly among pine and birch stands within the habitat types studied. Additionally, we assumed that (4) the 
leaf litter type (alder, birch, oak, pine,) would significantly affect the assemblages of predatory mites. Along with decomposition, (5) the abundance and species richness would differ significantly among collection dates, with the highest values in the middle of the period studied.

\section{Material and Methods}

\subsection{Site Description and Experimental Design}

The study was conducted on the external spoil heap of the "Bełchatów" lignite mine (Mount Kamieńsk, Central Poland; 51.2151, 19.4345) and in the surrounding forests managed by the State Forests, representing different habitat types. Growing season length for this region is 210-220 days [49]. Average annual precipitation for this location was $665 \mathrm{~mm}$ and the annual air temperature was $8.65{ }^{\circ} \mathrm{C}$ during 1995-2015 (data for the nearest meteorological station, i.e., 51.4319, 19.2353, $179 \mathrm{~m}$ a.s.1.).

On both habitat types (spoil heap and forest, hereafter known as SH and FH, respectively), four pure stands were selected for further investigation, i.e., two silver birch (Betula pendula Roth) and two Scots pine (Pinus sylvestris L.) stands, hereafter known as Bp and Ps, respectively. The studied stands in both habitats grow in close vicinity to each other (up to $6 \mathrm{~km}$ ). For comparison of ecological features they had to meet the following criteria: same species, similar age, identical soil granulometry, and comparable stand structure. Because of initial soil substrates on the spoil heap it was inherently hard to meet all the mentioned criteria. This is the reason that two of the birch stands are relatively close to each other (Table A1). The external spoil heap has a relative altitude of ca. $190 \mathrm{~m}$ above the surrounding landscape [50], and was formed during 1977-1993 [51]. The total area of the spoil heap is $1471 \mathrm{ha}$, which is the largest post-industrial area in the Centro-European Lowlands [49]. The soil substrate of the spoil heap is very differentiated from surrounding habitats. It is poor in nutrient contents and organic matter, and contains toxic Tertiary substrates elements in some places on the top [49]. The most frequent soils are Quaternary loamy, gravelly sands which sporadically comprise loam and clays. Highly acidic $(\mathrm{pH}<4.5)$ Tertiary sandy strata with clay and loam inclusions also occur on the spoil heap [52].

Almost the whole reclaimed spoil heap, which was recultivated with trees, is afforested and $54 \%$ covered by young stands $26-31$ years old (data for 2016) [46]. The most common herbaceous species in the herb layer were Calamagrostis epigejos (L.) Roth, Dactylis glomerata L. (abundant in birch plots, occasionally in pine plots), Festuca rubra L. (abundant in birch as well as in pine plots) and Taraxacum officinale F. H. Wigg. group (occasionally in birch, as well as in pine plots) [53]. In the herbaceous layer of research plots located on adjacent forest habitats the dominant vascular plant species were Carex ovalis Good. (abundant in birch plots, occasionally in pine plots), Vaccinium myrtillus L. (abundant in pine plots) and Moehringia trinervia (L.) Clairv. (occasionally in birch plots), whereas mosses were Brachythecium rutabulum (Hedw.) Schimp. (abundant in birch plots, occasionally in pine plots), Polytrichastrum formosum (Hedw.) G.L.Sm. (occasionally in birch and pine plots) and Atrichum undulatum (Hedw.) P.Beauv. (occasionally in birch plots) [45].

The experiment lasted for three years and was performed between 2013 and 2016. In December 2013, fiberglass litterbags containing oven-dried (dried at $65{ }^{\circ} \mathrm{C}$ ) fallen leaves (mean initial dry weight $=5.789 \mathrm{~g}$ ) of one of the four tree species (alder, birch, oak and pine), which were collected ex situ in the autumn of the same year, were laid out on the study plots. The number of research plots was 8 ( 2 plots per habitat type-stand type variant) (Table A1). Mesh size of the litterbags ( $1 \mathrm{~mm})$ was chosen so that individuals of the investigated group of soil fauna moved freely through the mesh and had full access to leaf organic matter [8]. We tried to mirror the natural way in which litter is decomposed just after falling onto the forest floor. The samples were laid out in randomly chosen rows. All litter used was collected in such a way as to maintain homogeneity and equality of the research material. The samples were displayed on uncovered mineral soil substrate in stands devoid of organic layers or on the fibric soil horizon in stands where the presence of a litter layer was noted. 
Overall, 1024 litterbags with leaves were laid out in an equal number to be collected at eight collection dates (128 samples: 2 habitat types $\times 2$ stand types $\times 2$ plots $\times 4$ litter types $\times 4$ samples per litter type). As a result of external factors, such as wildlife activity, eight samples were destroyed and omitted from further analysis. During our experiment, the litterbags were collected after 3, 6, 9, 12, 18, 24,30 and 36 months after exposure on the plots. After extraction of soil invertebrates (see paragraph 2.2.), in order to determine the rate of decomposition, leaves were dried at $65{ }^{\circ} \mathrm{C}$ to obtain a constant dry mass, then the mass loss was determined in relation to the initial litter mass in every litterbag [54].

\subsection{Soil Mite Investigation}

Mites were extracted from litter samples using Berlese-Tullgren funnels with a $2 \mathrm{~mm}$ mesh size. The temperature and moisture gradient in the funnels forced soil fauna to move down, directly into containers with $75 \%$ ethyl alcohol. The extraction process of edaphic fauna lasted a minimum of 6 days, until the collected samples were completely dry. Mesostigmatid mites were separated from other soil organism groups, previously extracted from litter samples, sorted under a stereomicroscope and put into $85 \%$ lactic acid for a minimum of 3 days to ensure maximum transparency of selected specimens. Furthermore, the mite specimens were identified to genus and species level and also all developmental stages were counted using acarological keys.

Additionally, in order to determine the ecological features of species composition within the habitats and stand types studied, we used the selection of mite species into exclusive, core and common taxa after Kamczyc et al. [55]. Core species were taxa which occurred on all habitats and stand types investigated, whereas exclusive species refer to taxa which were present in only one stand type. Common species were taxa inhabiting and indicated from a minimum of two stand types. Similar divisions were made by Skubała [56], and Ulrich and Zalewski [57].

\subsection{Statistical Analysis}

Two-way analysis of variance (ANOVA) assuming zero inflated Poisson distributions (ZI Poisson) was conducted to determine the influence of factors studied (habitat type, stand type, litter type and collection month) on mesostigmatid mite abundance and species richness. We calculated the mean number of mite individuals and mean number of species per sample. We were able to compare 1016 observations with the factors examined. Results were considered significant when $p<0.05$. In addition, Tukey's HSD (honestly significant difference) test was used to determine the similarity and differences between the averages obtained. Additionally, we conducted correspondence analysis (CA) for the 25 most numerous mite taxa $(n>10)$ to show site preferences, as well as the correlation of occurrences of mite taxa and environmental types (habitat type and stand type) [56,58]. Statistics were done with the software package JPM Pro 13 (https:/ / www.jmp.com; SAS Institute Inc. Cary, NC, USA).

\section{Results}

\subsection{Mite Abundance}

In total, 6466 mite individuals were recorded. Overall, higher total abundance was recorded from stands growing in FH (5174 ind. = individuals) than from the SH (1292). Total number of mite individuals was higher in Bp in comparison with Ps stands, both in FH (3345 vs. 1829 ind., respectively) and SH (981 vs. 311). The highest total number of mites was found in litterbags with oak litter (2063 ind.), whereas for other litter types total abundance was similar (interval: 1455-1482). In Bp growing in FH, total mite abundance was 6.7 (alder), 5.1 (pine), 3.6 (birch) and 1.9 (oak) fold higher than on the SH. In Ps stands growing in FH, total mite number was 8.7 (alder), 7.3 (birch), 4.8 (oak) and 4.7 (pine) fold higher than on the SH (Table A2). In each collection date, the total mite abundance was highest in $\mathrm{Bp}$ stands growing in $\mathrm{FH}$; only after 2 years from the beginning of the experiment, were there similar total abundances in Ps and Bp stands growing in FH (358 and 350 ind., respectively). Single specimens were found only after 3 and 30 months from the beginning of the experiment in 
Ps stands on both habitats, as well as in Bp stands on the SH. After 6 months from the beginning of the study no mites were found on the SH. Altogether, the highest total number of mites was found 9 months after establishment of the experiment (1817 ind.), whereas the lowest numbers were found after 3 and 30 months (295 and 216, respectively) (Figure 1).

We found a statistically significant influence of all examined factors on mean number of mite individuals per sample (habitat type (HT) $-p<0.0001$, stand type (ST) $-p=0.0077$, collection month $(\mathrm{CM})-p<0.0001$, litter type (LT) $-p=0.0374)$. Considering the interaction between collection month (CM) with other factors (HT, ST, LT), all interactions significantly influenced the total number of mites per sample $(\mathrm{CM} \times \mathrm{LT}-p<0.0001, \mathrm{CM} \times \mathrm{HT}-p<0.0001, \mathrm{CM} \times \mathrm{ST}-p<0.0001)$ (Table 1). Mean mite abundance per sample was significantly higher in $\mathrm{FH}$ (10.13 \pm 0.36 ind.) in comparison with the SH $(2.53 \pm 0.36)$. Higher mean number of mite individuals per sample was recorded from Bp stands (13.07 \pm 0.50 ind. for FH and $3.85 \pm 0.51$ for SP) in comparison to Ps stands (7.20 \pm 0.51 and $1.22 \pm 0.50$, respectively). Among litter types, mean mite numbers were significantly higher only for oak litter (8.07 \pm 0.50 ind.), while alder (5.80 \pm 0.51$)$, pine $(5.73 \pm 0.51)$ and birch $(5.73 \pm 0.50)$ had similar mean mite abundance per sample. Overall, considering the time factor (collection month), the highest mean abundance per sample was recorded in the 9th month after the beginning of the experiment (14.12 \pm 0.71 ind.), while the lowest value was found in the 30th month $(1.69 \pm 0.71)$ of the study.

\subsection{Mite Species Richness}

In general, higher total numbers of mite species were found in FH (49 taxa) than on the SH (29). Moreover, higher values were recorded from Bp stands (37 species) in comparison to Ps stands (30) in $\mathrm{FH}$. On the other hand, on the $\mathrm{SH}$, the total number of species recorded was similar between $\mathrm{Bp}$ and Ps stands, with 22 and 21 species, respectively. The highest number of species was found for oak litter (43 taxa), whereas the least was for alder litter (33). Pine and birch litter had the same total number of taxa (39) (Table A3). Additionally, total species richness in pooled data ranged from 7 species (3rd month) to 38 species (9th month). A similar pattern was observed for habitat types separately. Total species richness varied from 6 species (3rd month) to 31 species (9th month) in FH, whereas on the $\mathrm{SH}$ it varied from 3 species (3rd month) to 19 species (9th month) (Figure 2).

We did not find statistically significant influences of habitat type $(p=0.2379)$, stand type $(p=0.8752)$, or litter type $(p=0.9633)$ on mean number of species per sample. Only collection month $(\mathrm{CM})$ had a significant influence $(p=0.0281)$. However, statistical analysis did not show statistically significant influences of interactions between time (CM) and the factors examined (CM $\times \mathrm{LT}-p=0.9673, \mathrm{CM} \times \mathrm{HT}-p=0.3371, \mathrm{CM} \times \mathrm{ST}-p=0.8126)$ on mean number of species per sample (Table 1). Overall, the mean number of mite taxa per sample differed between the habitats studied. Higher mean number of species per sample was recorded in $\mathrm{FH}$ ( $2.55 \pm 0.06$ taxa) compared to $\mathrm{SH}(0.77 \pm 0.06)$. Moreover, higher mean number of species per sample was recorded from $\mathrm{Bp}$ stands ( $3.31 \pm 0.08$ taxa in $\mathrm{FH}$ and $0.91 \pm 0.08$ on $\mathrm{SH})$ in comparison to Ps stands $(1.77 \pm 0.08$ and $0.63 \pm 0.08$, respectively). We also noted that the highest mean number of taxa per sample was for oak litter $(1.84 \pm 0.08$ taxa), while the lowest value was recorded in birch litter $(1.51 \pm 0.08)$. A Tukey test showed that both these types of litter were significantly different from alder ( $1.55 \pm 0.08$ taxa) and pine litter $(1.71 \pm 0.08)$. Furthermore, the highest mean number of mite taxa per sample was recorded for the 9th month $(3.33 \pm 0.11$ taxa), while the lowest value was in the 3rd month $(0.21 \pm 0.11)$. A Tukey test revealed that only the 9 th collection month was significantly different from others. 


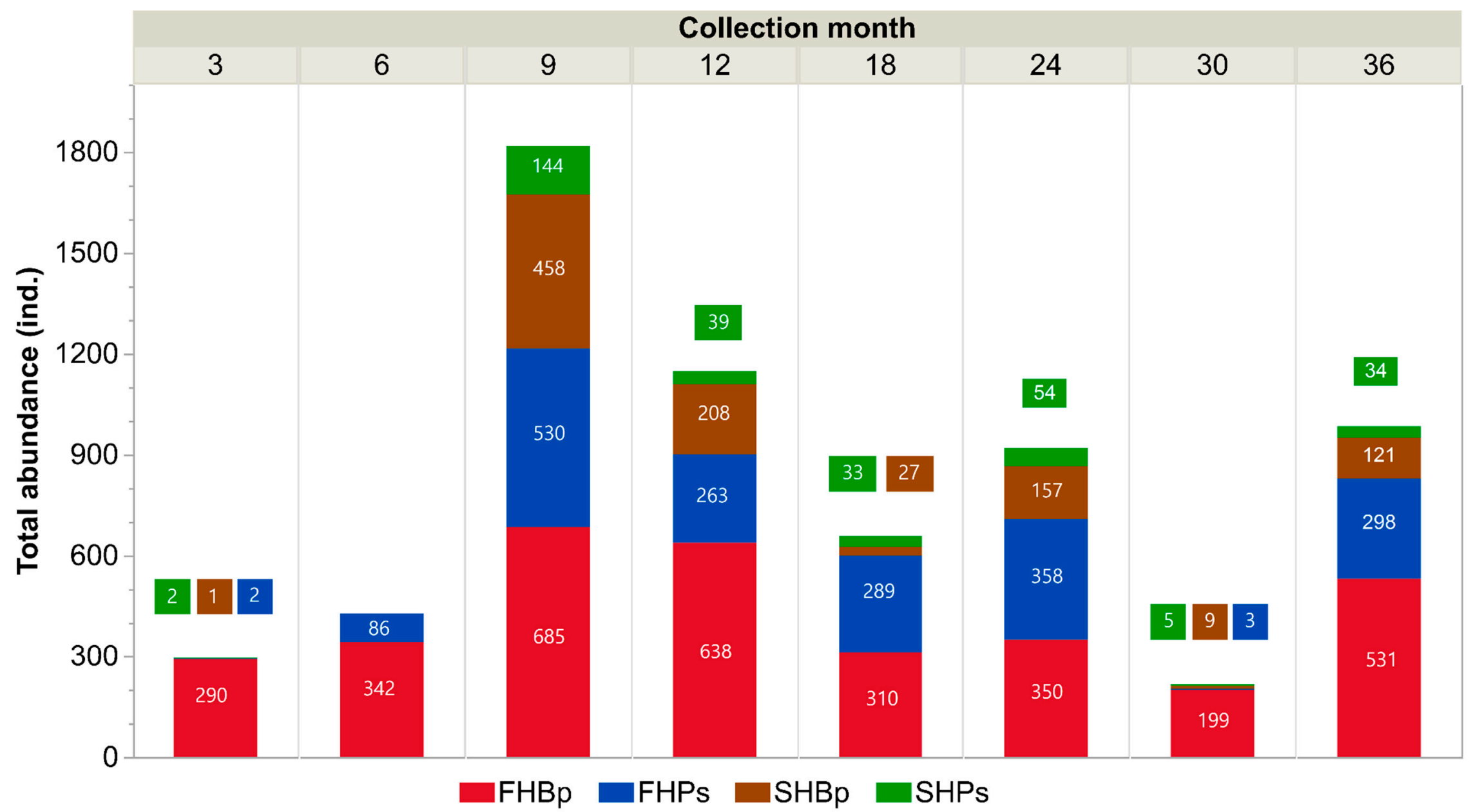

Figure 1. Number of gamasid mite individuals collected in Betula pendula Roth (Bp) and Pinus sylvestris L. (Ps) stands growing in forest habitat (FH) and spoil heap $(\mathrm{SH})$ by collection month during the experiment. When total abundance was very low, we have added numbers and respective colors above the bars. 
Table 1. Two-way analysis of variance (ANOVA) assuming zero inflated Poisson distributions (ZI Poisson) for mean abundance and mean species richness per sample. Abbreviations: DF—degrees of freedom, CM—collection month, LT—litter type, HT—habitat type, ST—stand type.

\begin{tabular}{|c|c|c|c|c|c|c|}
\hline \multirow{2}{*}{ Fixed Factor } & \multicolumn{2}{|c|}{ DF } & \multicolumn{2}{|c|}{ Wald Chi-Square } & \multicolumn{2}{|c|}{ Prob > Chi-Square } \\
\hline & Abundance & Species Richness & Abundance & Species Richness & Abundance & Species Richness \\
\hline $\mathrm{CM}$ & 7 & 7 & 141.972 & 15.689 & $<0.0001$ & 0.0281 \\
\hline LT & 3 & 3 & 8.461 & 0.282 & 0.0374 & 0.9633 \\
\hline HT & 1 & 1 & 22.590 & 1.393 & $<0.0001$ & 0.2379 \\
\hline ST & 1 & 1 & 7.111 & 0.025 & 0.0077 & 0.8752 \\
\hline $\mathrm{CM} \times \mathrm{LT}$ & 21 & 21 & 78.628 & 10.756 & $<0.0001$ & 0.9673 \\
\hline $\mathrm{CM} \times \mathrm{HT}$ & 7 & 7 & 1365.612 & 7.949 & $<0.0001$ & 0.3371 \\
\hline $\mathrm{CM} \times \mathrm{ST}$ & 7 & 7 & 69.675 & 3.709 & $<0.0001$ & 0.8126 \\
\hline $\mathrm{LT} \times \mathrm{HT}$ & 3 & 3 & 6.848 & 2.115 & 0.0769 & 0.5489 \\
\hline $\mathrm{LT} \times \mathrm{ST}$ & 3 & 3 & 10.256 & 1.578 & 0.0165 & 0.6644 \\
\hline $\mathrm{HT} \times \mathrm{ST}$ & 1 & 1 & 0.797 & 1.159 & 0.3719 & 0.2818 \\
\hline $\mathrm{CM} \times \mathrm{LT} \times \mathrm{HT}$ & 21 & 21 & 917.881 & 14.963 & $<0.0001$ & 0.8248 \\
\hline $\mathrm{CM} \times \mathrm{LT} \times \mathrm{ST}$ & 21 & 21 & 237.841 & 12.251 & $<0.0001$ & 0.9326 \\
\hline $\mathrm{CM} \times \mathrm{HT} \times \mathrm{ST}$ & 7 & 7 & 12.618 & 1.931 & 0.082 & 0.9635 \\
\hline $\mathrm{LT} \times \mathrm{HT} \times \mathrm{ST}$ & 3 & 3 & 5.563 & 1.153 & 0.1349 & 0.7644 \\
\hline $\mathrm{CM} \times \mathrm{LT} \times \mathrm{HT} \times \mathrm{ST}$ & 21 & 21 & 69.846 & 14.247 & $<0.0001$ & 0.8588 \\
\hline
\end{tabular}




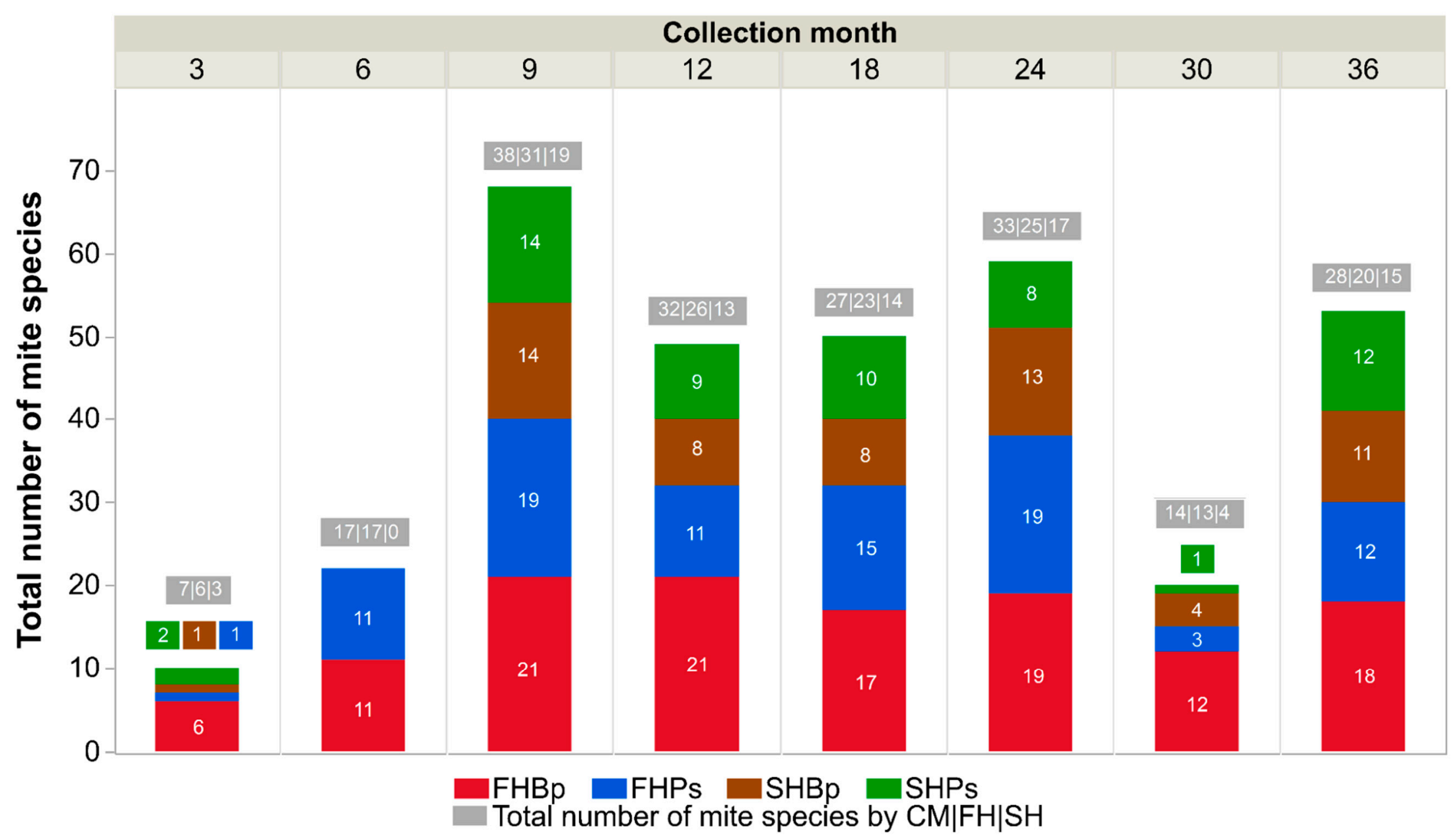

Figure 2. Total number of mite species recorded in Betula pendula (Bp) and Pinus sylvestris (Ps) stands growing in forest habitat (FH) and spoil heap (SH). Data are shown for each collection month (CM) during the experiment. When total abundance was very low, we have added numbers and respective colors above the bars. 


\subsection{Mite Assemblages}

In general, mite communities were dominated by Zercon peltatus C.L. Koch (2281 ind.) and Veigaia nemorensis C.L. Koch (892). The mite communities on the SH, both in Bp and Ps stands, were dominated by Amblyseius tubae Karg (740 ind.). In Ps stands, in terms of juvenile stadia, individuals described to the genus Pergamasus sp. predominated (35 ind.), while in Bp stands it was A. tubae (24). FH was dominated by mites belonging to Z. peltatus (2264 ind.). However, Bp stands were characterised by higher numbers of juvenile mite instars of $V$. nemorensis (345 ind.) and Trachytes aegrota C.L. Koch (323) than Z. peltatus (219), whose juvenile forms dominated in Ps stands (492) (Table A4).

In total, $70.6 \%$ of mites collected during the experiment were adults. In general, in mature stadia the majority were female mites $(85.5 \%)$, which were the dominant form in each type of habitat and stand. For juvenile stages, deutonymphs predominated (53.9\% of all juvenile forms), except for the Bp stands growing on the $\mathrm{SH}$, where abundance of protonymphal forms was much higher $(178.3 \%$ of deutonymphs). The larval stages were predominant in FH (204 ind.), and more larvae were found in Ps stands (145) in comparison with Bp stands (59), while on the SH only single larval stages were recorded (3) (Table A4).

We found that 8 taxa were core species (A. tubae, Asca aphidioides Linneaeus, Leptogamasus parvulus Berlese, Paragamasus runcatellus Berlese, Paragamasus sp., Pergamasus crassipes Linneaeus, Pergamasus sp., Z. peltatus), which occurred in both Bp and Ps stands and on SH and FH. In total, 32 species were described as exclusive taxa, occurring only in one type of habitat (habitat type $\times$ stand type). The highest number of exclusive species were found in Bp stands growing in FH (14 taxa), whereas the least occurred in those on the SH (3). Six common taxa were described on the SH for both types of stands, while there were 10 in the FH. The number of common mite species found in Bp stands occurring on both habitats was 7 taxa, while in the Ps stands there were 4 taxa. Among the most abundant 6 species (dominance $>1 \%$ ) (see Table A4), half were core species (A. tubae, A. aphidioides, Z. peltatus). The other 3 taxa (Olodiscus minima Kramer, T. aegrota, V. nemorensis) were characterized as common species (Figure 3).

As a part of previous research (2011-2013) (for more details see Piasta et al. [34]), soil samples were taken to the depth of $5 \mathrm{~cm}$ (steel core- $40 \mathrm{~cm}^{2}$ ) on the same plots included in this study, to investigate gamasid mite assemblages. The comparison of the data showed that $56.9 \%$ of total mite species identified previously in the soil samples also inhabited litterbags in our study. Comparing the SH with $\mathrm{FH}$, the percentage of taxa that occurred in the top layer of soil on the plots and that also colonized the litterbags was similar, $63.0 \%$ and $58.8 \%$, respectively. Similar SH and FH comparisons for Ps stands were $62.5 \%$ and $67.7 \%$, and for Bp stands, $70.0 \%$ and $50.0 \%$, respectively. Moreover, it was found that P. crassipes was the only species that commonly occurred in the soil on all research plots, regardless of HT and ST, and also inhabited decomposing litter.

The correspondence analysis (CA) revealed that there were differences in the site (HT and ST) preferences of indicated species (Figure 4). Axis 1 and 2 explained $62.6 \%$ and $21.4 \%$ of variance, respectively. Based on the CA diagram, it can be noted that only two species, Veigaia cervus Kramer and Pergamasus septentrionalis Oudemans, were not characterized by evident preferences for type of habitat. However, $V$. cervus prefers Ps stands, while P. septentrionalis prefers Bp stands. The taxa which preferred FH and Ps stands were Z. peltatus, Trichouropoda ovalis C.L. Koch, Paragamasus sp., L. parvulus, Paracercon radiatus Berlese and Prozercon kochi Sellnick. At the same time, the last three species evidently preferred Ps stands in comparison to Bp stands growing in FH. On the other hand, species that preferred Bp stands in FH were: Paragamasus jugincola Athias-Henriot, V. nemorensis, T. aegrota, O. minima, Epicriopsis horridus Kramer, Iphidiozercon gibbus Berlese, Veigaia planicola Berlese and P. runcatellus. On the SH, there were taxa that strongly preferred Bp stands, i.e., Amblyseius sp., A. tubae and Asca bicornis Canestrini et Fanzago, while Ps stands were the preferred habitat of P. crassipes, Hypoaspis praesternalis Willmann and Arctoseius insularis Willmann. Despite their numerous occurrence on the SH area, Pergamasus sp., Paragamasus conus Karg and A. aphidioides were characterized by high preferences towards the FH (Figure 4). 
Our results revealed that the colonization rate of litterbags varied. Comparing the habitat and stand types in terms of succession of the most abundant species among stand types (Dominance > $1 \%$ ), it can be noted that the colonization of decaying litter occurred faster in FH compared to the $\mathrm{SH}$. Only in FH were species recorded that were present throughout the whole duration of the experiment. These species were Z. peltatus in Ps stands, and V. nemorensis, T. aegrota and Z. peltatus in Bp stands. Among the dominant taxa for a given stand and habitat type, only Z. peltatus (Ps stands in FH) and A. tubae (Bp stands on the $\mathrm{SH}$ ) were dominant throughout the entire duration of the experiment. In Ps stands growing on $\mathrm{SH}$ it was noted that a different mite species prevailed at each collection month, omitting a single specimen of $A$. insularis in the 3rd collection month. Moreover, in Bp stands growing in FH Z. peltatus dominated only in the 3rd, 6th and 24th, 30th collection months, while in the middle months (12th,18th) and in the last month (30th), the dominant species was V. nemorensis. Abundance and species richness of mite assemblages in the culmination month (9th month), differed in each stand type within habitat types. Bp stands were dominated by T. aegrota and A. tubae, while Ps stands by Z. peltatus and A. bicornis, in FH and $\mathrm{SH}$, respectively. The critical point in the succession of mite assemblages was the 30th month of the study, when only in the Bp stands in FH were all of the six most abundant species in the stand type recorded (Table A5).

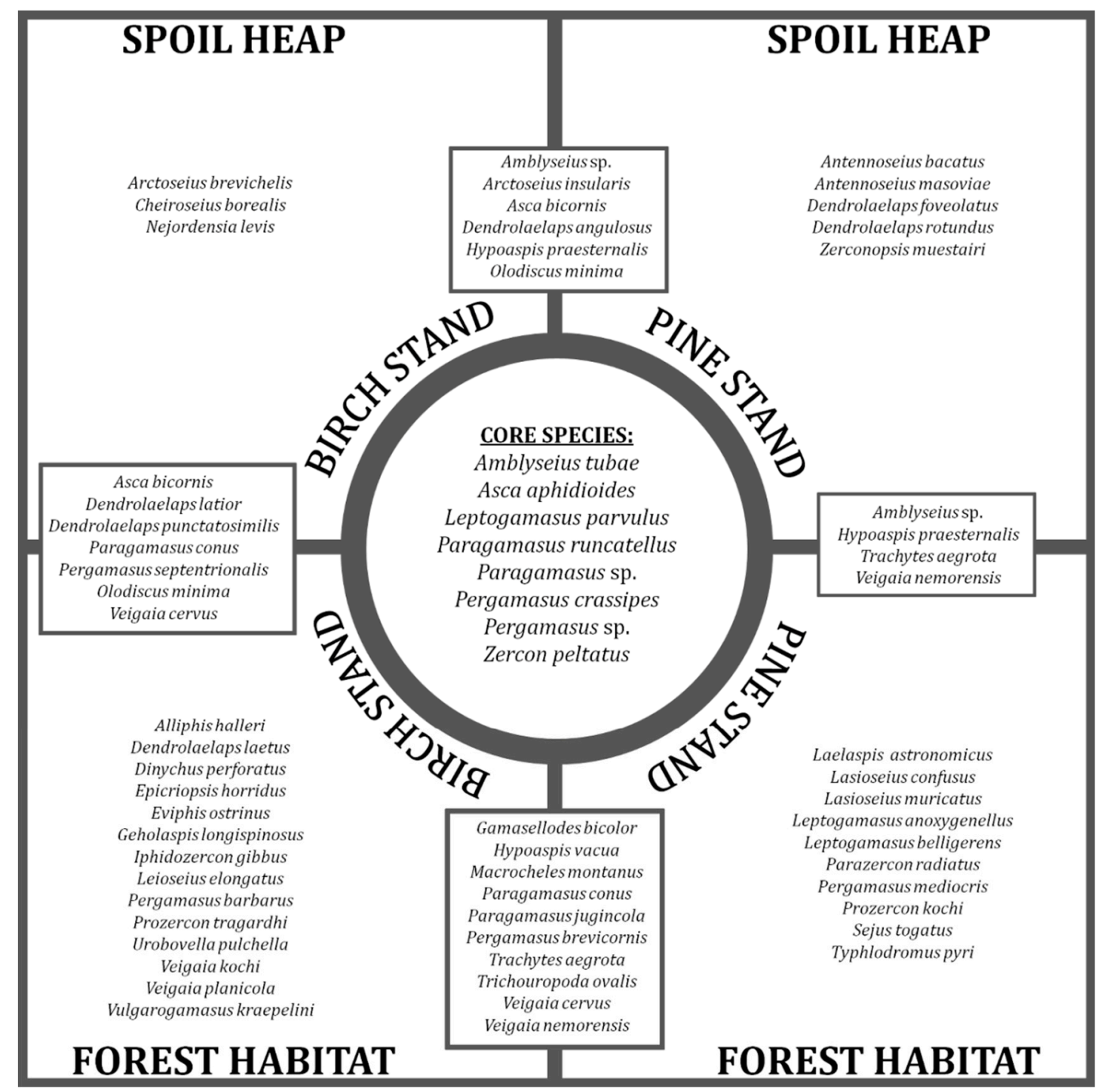

Figure 3. Core, exclusive and common (in frames) mite species in Betula pendula (Bp) and Pinus sylvestris (Ps) stands growing in forest habitat (FH) and spoil heap (SH). 


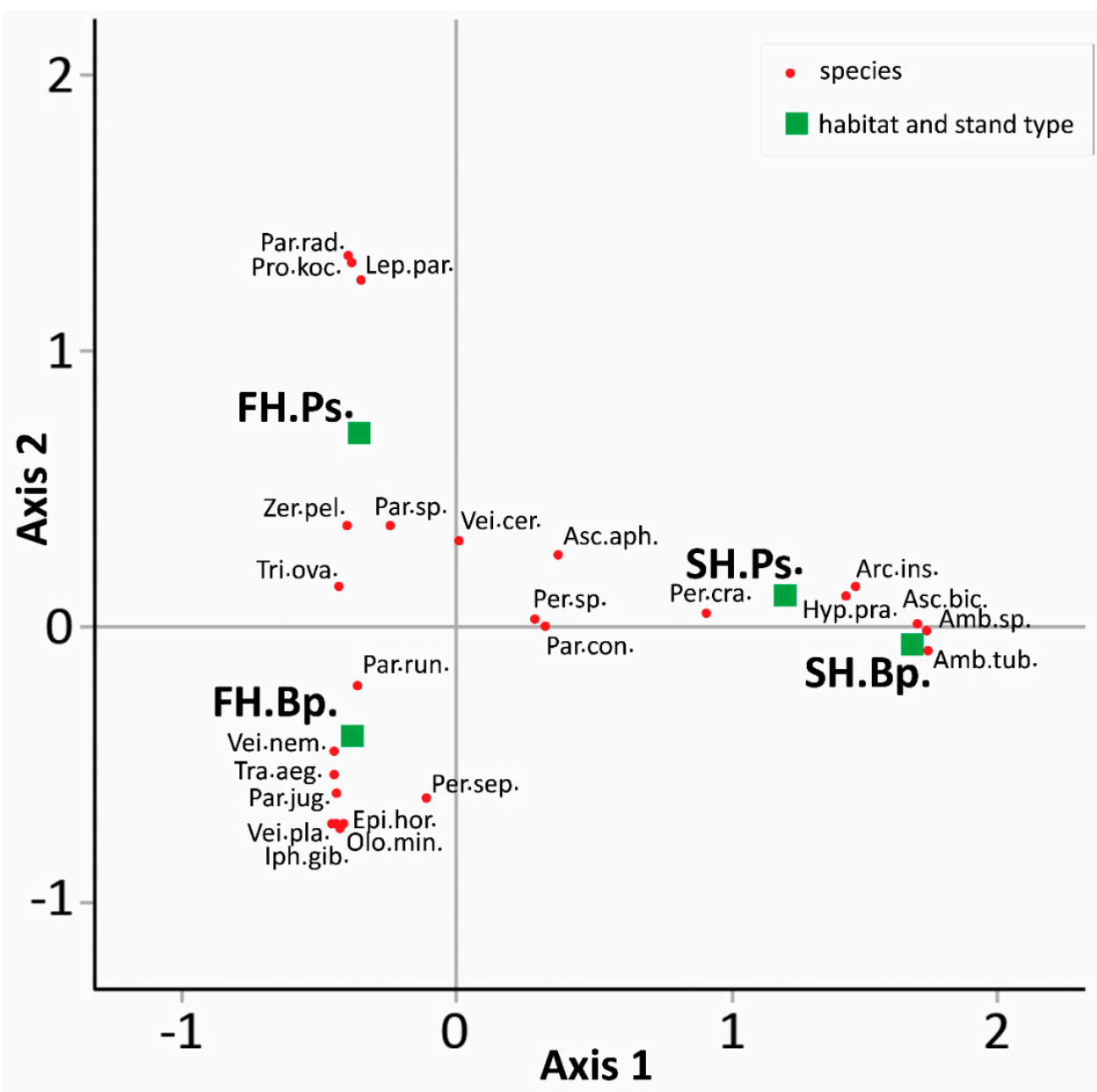

Figure 4. Correspondence analysis (CA) ordination diagram for the 25 most numerous mite taxa $(n>10)$. Habitat types are separated along Axis 1, while stands types are separated along Axis 2. Abbreviations: FH.Bp.-forest habitat-birch stand, FH.Ps.-forest habitat-pine stand, SH.Bp.-spoil heap-birch stand, SH.Ps.-spoil heap-pine stand, Amb.sp.-Amblyseius sp., Amb.tub.-Amblyseius tubae Karg, Arc.ins.-Arctoseius insularis Willmann, Asc.aph.—Asca aphidioides Linneaeus, Asc.bic.-Asca bicornis Canestrini et Fanzago, Epi.hor.-Epicriopsis horridus Kramer, Hyp.pra.-Hypoaspis praesternalis Willmann, Iph.gib._Iphidiozercon gibbus Berlese, Lep.par._Leptogamasus parvulus Berlese, Par.con._Paragamasus conus Karg, Par.jug._Paragamasus jugincola Athias-Henriot, Par.rad.-Parazercon radiatus Berlese, Per.run.-Pergamasus runcatellus Berlese, Par.sp._Paragamasus sp., Per.cra._Pergamasus crassipes Linneaeus, Per.sep.-Pergamasus septentrionalis Oudemans, Per.sp._Pergamasus sp., Pro.koc.-Prozercon kochi Sellnick, Tra.aeg.-Trachytes aegrota C.L. Koch, Tri.ova.-Trichouropoda ovalis C.L. Koch, Olo.min.-Olodiscus minima Kramer, Vei.cer.-Veigaia cervus Kramer, Vei.nem._Veigaia nemorensis C.L. Koch, Vei.pla._Veigaia planicola Berlese, Zer.pel.-Zercon peltatus C.L. Koch.

\section{Discussion}

We found a statistically significant influence of collection month on abundance and species richness of gamasid assemblages, whereas habitat type, stand type and litter type had a significant influence only on mesostigmatid abundance. Also, we revealed significant changes in species composition of gamasid community structure involved with the decomposition process during the period studied. Lower total abundance and number of taxa were recorded from the SH ( $20 \%$ of total abundance, 29 taxa) in comparison to the adjacent FH (80\%, 49 taxa). Similar results were obtained in research investigating orbibatid mite assemblages by Murvanidze et al. [14] and Skubała [56], which also proved the negative influence of sand-manganese and coal mine dumps, respectively, on 
abundance and species richness compared with surrounding forests. Skubała [56] indicated 3 times higher mean abundance in adjacent forests in comparison to the highest recorded values on dump sites studied, whereas Murvanidze et al. [14] found that $40 \%$ of taxa (35 of 89 species) occurred only in adjacent forests compared with degraded sites. This may be explained by the fact that colonization rate is limited and impeded on newly formed soils [13]. Soil biological activity on degraded lands is relatively low $[33,59]$ due to disturbed structure of the soil profile, and lack of appropriate water and air conditions [6] or amount of organic matter [7], whereas on undisturbed habitats, such as forest habitats, the upper layer of soils may be well covered by a litter layer [60] or vegetation which can be important buffers in ecologically stressful situations, for example droughts [19].

Likewise, we recorded a significant influence of stand type growing on both investigated habitats on mite assemblages, and proved the higher abundance and species richness in Bp stands in comparison to Ps stands. Our results are in line with previous investigations. For example, Mueller et al. [37] revealed that type of tree (evergreen or deciduous) and tree species significantly affected abundance and diversity soil invertebrate assemblages; however, they did not record significant differences in taxa richness for gamasid mite assemblages which potentially could have been affected by the factors examined. Also Skorupski [38] found significant differences between the stand types studied. He reported the highest species number in silver birch stands, whereas the lowest (half that in birch stands) occurred in coniferous stands of Douglas fir (Pseudotsuga menziesii (Mirb.) Franco). On the other hand, Gonzalez et al. [61] compared lodgepole pine (Pinus contorta Dougl. ex Loud.) and aspen (Populus tremuloides Michx.) stands. Their investigation showed that there was no significant influence of forest type on microarthropod density. Nevertheless, they revealed higher relative density of macroarthropods and earthworms per square meter in broadleaved stands than in coniferous stands. Also Pastwik et al. [32] reported that deciduous stands create better microclimate conditions for mite assemblages in comparison with coniferous stands; however, they revealed the highest total abundance from Scots pine stands (31\% of total mite numbers). Differences between arthropod groupings occurring in varied habitats and stands could be related to site features and variables in the microenvironment, e.g., litter carbon concentration, nitrogen content [62], soil and litter temperature or moisture [42] which depend on tree species that dominate a given stand [35,36,38].

We also recorded that the number of species was not influenced by litter type. Those results are in contrast to investigations of Frouz [9] and Fujii and Takeda [3], who proved the significant influence of characteristics and type of litter on macrofauna and various groups of microarthropods, respectively. Moreover, the removal of litter layer was also found to reduce mite community richness and abundance [63]. Surprisingly, we found impacts of litter type on mite abundance which is in line with the cited authors $[3,9]$. However, in our study total mite abundance on decomposing pine needles was similar to birch and alder leaves. This is in contrast to Gonzalez et al. [61] who revealed two times higher mite density (three times higher for gamasid mites) from broadleaf litter in comparison with pine needles. Furthermore, Kaneko and Salamanca [41] also reported 2.5 times higher gamasid abundance, or even three times higher in the second year of investigation, from oak litter compared to pine needles. They also revealed that litter structure might affect litter microclimate, and they also showed significant differences in microarthropod assemblages depending on litter type and whether the litter was single- or mixed-species. Likewise, the fact that in our experiment the oak litter was significantly different from other leaf types might be explained by its different lignin content [64] or a different decomposition rate, which depends on lignin content, as well as microand macroelements [36,54]. According to Osler et al. [65] decomposition rate is strongly correlated with microarthropod assemblages, however, only after $20 \%$ litter mass loss of the initial weight. Thus, the rate of decomposition can strongly differentiate the abundance and species richness of mite communities. Research conducted by Horodecki and Jagodziński [46] revealed that the decomposition rate of oak litter is the slowest among the examined litter types. Thus, a statistically significant, higher colonization rate of oak litter in comparison with other litter types studied, revealed in our study, might result from slower degradation rate of oak leaves compared to other leaf litter. Thus, as we 
assume, this may be associated with longer periods of habitation by soil organisms, which take a direct part in decomposition and are also part of the foodweb for predatory gamasid mites [3,19].

Altogether, the data obtained showed that with the passage of time (CM factor), and thus along with the ongoing decomposition, the abundance and species richness of mite assemblages changed significantly. However, we did not record the highest values for abundance and species richness in the middle of the period studied. The highest values were recorded in the 9th month after leaf litter samples were placed on the plots, and declines were recorded in the 30th collection month. This is opposite to the results obtained by Gonzalez et al. [61], who reported the initial increase, then the highest values in the middle of the two-year study period and the final decline in density of the soil fauna examined. Nonetheless, in research conducted by Osler et al. [65] the highest values of mite individuals and species per sample were found in the initial phases of the succession investigated, which coincides with results of this study. Furthermore, Berg et al. [16] obtained results similar to ours. They reported that, along with progressive litter decay, more precisely pine needles, there was an initial rapid increase in the density of predatory mites per square meter, and then a decrease in the number of specimens of predatory mites. However, as in our research, Berg et al. [16] noted a rapid drop in abundance of the mite group studied in one collection month, which they supposed was caused by the occurrence of drought in the study area. This violent collapse is in line with our results (see 30th collection month) where a rapid drop in recorded abundance of gamasid specimens also occurred. However, it was not affected by severe changes in decomposition rate of the litter type samples studied [54], but it might be a result of high average temperature $\left(18.6^{\circ} \mathrm{C}\right)$ and low precipitation (monthly precipitation sum $=67.5 \mathrm{~mm}$ ) (data for the nearest meteorological station, i.e., 51.4319, 19.2353, $179 \mathrm{~m}$ a.s.l.) in June 2016, and thus it might be a differences in soil moisture and aeration conditions $[19,65]$. In general, we also assumed that our results might be explained by the diversified rates of litter degradation [46], and thereby changes in the complexity of microenvironments within the decomposing leaves, which, as reported by Schmidt [66], affect the distribution of mites. In our results, it might also be explained by decreasing mass of litter used in litterbag samples [54]. Furthermore, the abundance and species richness of gamasid mites might also depend on the presence/absence of their prey, e.g., springtails, oribatids or nematodes [19]. The density of oribatid mites, as was reported by Maraun and Scheu [67], increases with the litter thickness. Also, Erdmann et al. [68] reported slower changes in oribatid assemblages which, as they supposed, may be caused by slow changes in structure of assemblages of bacteria and fungi, or the colonization rate of macrofauna. Vreeken-Buijs and Brussaard [24] proved that the decomposition rate was predator controlled. Moreover, they found that litterbags were colonized by bacterivorous nematodes and nematophagous mites in the first phase of decomposition, whereas only in the later phases were they colonized by predatory mites and fungivorous or omnivorous springtails and mites. This is in line with our results where, during the first phase of decomposition in FH (3rd, 6th and 9th collection month), we recorded an increase in abundance and numerous occurrences of Zercon peltatus C.L. Koch specimens, a predatory mite species belonging to the nematophagous Zerconidae family. Afterwards, in the following collection months, the number of individuals of other predatory mite taxa increased and Z. peltatus individuals declined, probably due to decreasing abundance of nematodes in litterbags. The diversified degree of settling or compaction of samples or different rates of colonization might be a result of biological characteristics and species ecology of mite taxa which create communities [20,29,33]. As was reported by Maraun and Scheu [67], we cannot say that single oribatid mite species prefer one type of stand, litter or tree species. However Bonari et al. [69] revealed that there was strong relationship of oribatid mites assemblages and examined vascular plants. Skorupski [38] found that Veigaia cervus Kramer was most numerous in mature Scots pine stands, which is similar to the results of Berg et al. [16], who also recorded a greater number of $V$. cervus in pine stands, over 19 times higher in comparison with abundance of Veigaia nemorensis C.L. Koch, which is in line with our results in terms of site preferences of these taxa. However, Pergamasus septentrionalis Oudemans was recorded more frequently by Skorupski [38] in coniferous stands than in broadleaved stands of common oak, which is the opposite of our CA analysis 
results for this species. Moreover, in this study we reported that, in terms of total abundance, the most dominant three species in Ps and Bp stands on the SH were Amblyseius tubae Karg, Asca bicornis Canestrini et Fanzago and Asca aphidioides Linneaeus, whereas in FH the dominant species were $Z$. peltatus and V. nemorensis (in both stand types), Trachytes aegrota C.L. Koch in Bp stands and Leptogamasus parvulus Berlese in Ps stands. Z. peltatus, T. aegrota and V. nemorensis, are species often reported from the top soil layer on forest sites. L. parvulus was reported from beech forests, especially from the moss and litter layer [70], whereas A. bicornis was classified as a pioneer mite species [22,31], often found on degraded habitats $[29,34]$ or was classified among those species that preferred reclaimed sites [27,34]. Also, A. aphidioides, as revealed by Skorupski et al. [33], is a pioneer species which was reported from derelict, as well as grassy, reclaimed areas or post-coal mining sites. Furthermore, the high abundance of $A$. tubae on the SH might also be a result of the ecological characteristics and site preferences of this species. Specimens of this species occurred in herb and shrub layers in mountain rocks, as well as in the dry moss layer and lichens. Moreover, $A$. tubae individuals were reported from grass roots and humus [70]. Madej [29] reported mite individuals of Amblyseius sp. as pioneer organisms that were plentiful inhabitants on degraded or initial lands. Piasta et al. [34], also revealed higher abundance of mite individuals of the genus Amblyseius sp. on the spoil heap (in soil samples) in comparison with adjacent forests, which is in line with our results.

\section{Conclusions}

In conclusion, our research revealed that habitat conditions, dominant tree species of stand and litter type, significantly determine the composition and abundance, but not the species richness, of mesostigmatid mite species. On the post-mining site, the rate of colonization by mites was slower than on adjacent forest habitat, whereas species richness was also lower, notwithstanding the fact that there was no significant influence of the time factor on mean number of taxa. Nevertheless, by selecting the tree species of stands during afforestation, it is possible to significantly affect the composition of soil gamasid mites, and thus indirectly the rate of decomposition on disturbed habitats. Moreover, our research revealed that adding admixture tree species, like common oak, within pure stands of Scots pine and silver birch (which are the most commonly used tree species in reclamation of post-mining areas), will certainly accelerate soil formation processes, due to the influence of increased biological activity of the soil mesofauna occurring in the litter of admixture species, and thus reduce the reclamation time of degraded soils, which can be reflected as biological, economic and management benefits.

Author Contributions: Conceptualization, A.M.J., M.S., C.K.U., P.H., and J.K.; Methodology, A.M.J., C.K.U., M.S., J.K., and P.H.; Software, C.K.U. and P.H.; Validation, C.K.U., A.M.J., J.K., P.H., and M.S.; Formal Analysis, C.K.U., J.K., M.S., A.M.J., and P.H.; Investigation, C.K.U., P.H., A.M.J., M.S., and J.K.; Resources, C.K.U., A.M.J., M.S., J.K., and P.H.; Data Curation, C.K.U., P.H., J.K., M.S., and A.M.J.; Writing-Original Draft Preparation, C.K.U., A.M.J., P.H., J.K., and M.S.; Writing-Review \& Editing, C.K.U., A.M.J., J.K., M.S., and P.H.; Visualization, C.K.U., and P.H.; Supervision, A.M.J., and J.K.; Project Administration, A.M.J.; Funding Acquisition, A.M.J., and M.S.

Funding: This study was supported by the General Directorate of State Forests, Warsaw, Poland (research project: 'Environmental and genetic factors affecting productivity of forest ecosystems on forest and post-industrial habitats', 2011-2015) and the Poznań University of Life Sciences, Faculty of Forestry, Poznań, Poland (grant no. 507.216.07).

Acknowledgments: The authors would like to thank Ewa Puchalska and Mariusz Lewandowski from the Department of Applied Entomology, Warsaw University of Life Sciences, Poland, for support in species determination of the Phytoseiidae family. We kindly thank Lee E. Frelich (University of Minnesota Centre for Forest Ecology, USA) for linguistic support and Marcin K. Dyderski (Institute of Dendrology, Polish Academy of Sciences, Kórnik, Poland) for valuable comments to the manuscript.

Conflicts of Interest: The authors declare no conflict of interest. 


\section{Appendix}

Table A1. Basic characteristics of sample plots (measurements were taken in 2011 and 2012). Abbreviations: Bp—Betula pendula Roth, Ps—Pinus sylvestris L., SH—spoil heap, FH—forest habitat, CL—clay loam, S—sand, SL—sandy loam, BA-basal area at breast height, DBH—diameter at breast height, H—tree height, SE—standard error, FPMD—fresh protomoder, FPM—fresh protomor, FMD—fresh moder, FMM—fresh modermor, FM—fresh mor.

\begin{tabular}{|c|c|c|c|c|c|c|c|c|c|c|c|c|}
\hline Plot No. & Coordinates & Plot Area $\left(\mathrm{m}^{2}\right)$ & $\begin{array}{l}\text { Stand } \\
\text { Type }\end{array}$ & $\begin{array}{c}\text { Habitat } \\
\text { Type }\end{array}$ & $\begin{array}{c}\text { Soil } \\
\text { Texture }\end{array}$ & $\begin{array}{c}\text { Humus } \\
\text { Type }\end{array}$ & $\begin{array}{c}\mathrm{pH} \mathrm{H}_{2} \mathrm{O} \\
\text { (O Layer) }\end{array}$ & $\begin{array}{c}\text { Stand Age } \\
\text { (years) }\end{array}$ & $\begin{array}{c}\text { Average DBH } \\
(\mathrm{cm})^{*} \pm \mathrm{SE}\end{array}$ & $\begin{array}{l}\text { Average } \mathrm{H} \\
(\mathrm{m}) * \pm \mathrm{SE}\end{array}$ & BA $\left(\mathrm{m}^{2} \mathrm{ha}^{-1}\right)^{*, * *}$ & $\begin{array}{l}\text { Stocking Density } \\
\left.\text { (ind. ha }^{-1}\right)^{*, * * *}\end{array}$ \\
\hline 6 & $\begin{array}{l}51.2207 \\
19.4339\end{array}$ & 604.5 & \multirow{2}{*}{ Bp } & \multirow{4}{*}{ SH } & CL & FPMD & 6.10 & 22 & $8.87(0.30)$ & $9.21(0.21)$ & $8.54(98.31)$ & 1274 (74.76) \\
\hline 7 & $\begin{array}{l}51.2208 \\
19.4339\end{array}$ & 604.5 & & & CL & FPMD & 6.12 & 22 & $8.96(0.34)$ & $9.09(0.22)$ & 7.4 (95.55) & 1075 (69.15) \\
\hline 15 & $\begin{array}{l}51.2105 \\
19.4384 \\
\end{array}$ & 900.0 & \multirow[b]{2}{*}{ Ps } & & $\mathrm{S}$ & FPM & 5.01 & 18 & $5.49(0.07)$ & $4.86(0.04)$ & $12.76(99.83)$ & $5022(99.12)$ \\
\hline 16 & $\begin{array}{l}51.2117 \\
19.4265\end{array}$ & 810.0 & & & $S$ & FPM & 4.93 & 17 & $6.81(0.11)$ & $6.05(0.05)$ & $20.61(99.96)$ & $5123(99.28)$ \\
\hline 105 & $\begin{array}{l}51.2744 \\
19.4324\end{array}$ & 646.5 & \multirow{2}{*}{ Bp } & \multirow{4}{*}{ FH } & SL & FMD & 5.55 & 20 & $10.40(0.21)$ & $13.66(0.11)$ & 15.79 (99.95) & $1779(92.00)$ \\
\hline 106 & $\begin{array}{l}51.2747 \\
19.4326\end{array}$ & 450.0 & & & CL & FMD & 5.57 & 20 & $10.10(0.20)$ & $13.44(0.12)$ & $18.32(99.99)$ & $2200(95.19)$ \\
\hline 107 & $\begin{array}{l}51.1738, \\
19.4323\end{array}$ & 750.0 & \multirow[b]{2}{*}{ Ps } & & $\mathrm{S}$ & FMM & 4.68 & 21 & $8.02(0.15)$ & $8.90(0.08)$ & $23.41(100.00)$ & $4200(99.68)$ \\
\hline 108 & $\begin{array}{l}51.1746, \\
19.4321\end{array}$ & 750.0 & & & S & $\mathrm{FM}$ & 4.37 & 21 & $8.46(0.16)$ & $9.16(0.08)$ & $21.22(99.81)$ & 3467 (99.24) \\
\hline
\end{tabular}

* including only main tree species in the stand; ** in the brackets, the share of BA of the main tree species in the stand in total BA is given; *** in the brackets, the share of stocking density of the main tree species in the stand in total stocking density is given. 
Table A2. Total abundance of mite individuals in four types of litter in Betula pendula (Bp) and Pinus sylvestris (Ps) stands growing in forest habitat (FH) and spoil heap (SH).

\begin{tabular}{|c|c|c|c|c|c|c|}
\hline \multirow{2}{*}{ Habitat Type } & \multirow{2}{*}{ Stand Type } & \multicolumn{4}{|c|}{ Litter Type } & \multirow{2}{*}{ Total } \\
\hline & & Birch & Oak & Alder & Pine & \\
\hline \multirow{2}{*}{$\mathrm{FH}$} & $\mathrm{Bp}$ & 760 & 942 & 860 & 783 & 3345 \\
\hline & Ps & 436 & 525 & 442 & 426 & 1829 \\
\hline \multirow{2}{*}{$\mathrm{SH}$} & $\mathrm{Bp}$ & 210 & 487 & 129 & 155 & 981 \\
\hline & Ps & 60 & 109 & 51 & 91 & 311 \\
\hline \multicolumn{2}{|c|}{ Total } & 1466 & 2063 & 1482 & 1455 & - \\
\hline
\end{tabular}

Table A3. Total number of mite species recorded in four types of litter in Betula pendula (Bp) and Pinus sylvestris (Ps) stands growing in forest habitat (FH) and spoil heap (SH).

\begin{tabular}{ccccccc}
\hline \multirow{2}{*}{ Habitat Type } & \multirow{2}{*}{ Stand Type } & \multicolumn{5}{c}{ Litter Type } \\
\cline { 3 - 6 } & & Birch & Oak & Alder & Pine & Total \\
\hline \multirow{2}{*}{ FH } & Bp & 22 & 23 & 25 & 26 & 37 \\
& Ps & 21 & 22 & 19 & 19 & 30 \\
\hline \multirow{2}{*}{ SH } & Bp & 15 & 19 & 8 & 16 & 22 \\
& Ps & 12 & 15 & 10 & 13 & 21 \\
\hline \multirow{2}{*}{ Total } & & 39 & 43 & 33 & 39 & - \\
\hline
\end{tabular}


Table A4. Checklist of mite species with number of individuals in Betula pendula (Bp) and Pinus sylvestris (Ps) stands growing in forest habitat (FH) and spoil heap (SH). The "-" signs were given to make the data table more transparent and should not be equated with the lack of results. Abbreviations: F-females, M-males, D-deutonymphs, P-protonymphs, L-larvae.

\begin{tabular}{|c|c|c|c|c|c|c|c|c|c|c|c|c|c|c|c|c|c|c|c|c|c|c|c|}
\hline \multirow{3}{*}{ No. } & \multirow{3}{*}{ Species } & \multirow{3}{*}{ Family } & \multirow{3}{*}{ Total No. of Specimens } & \multicolumn{10}{|c|}{ FH } & \multicolumn{10}{|c|}{ SH } \\
\hline & & & & \multicolumn{5}{|c|}{ Bp } & \multicolumn{5}{|c|}{ Ps } & \multicolumn{5}{|c|}{ Bp } & \multicolumn{5}{|c|}{ Ps } \\
\hline & & & & $\mathbf{F}$ & $\mathbf{M}$ & D & $\mathbf{P}$ & $\mathbf{L}$ & $\mathbf{F}$ & $\mathbf{M}$ & D & $\mathbf{P}$ & $\mathbf{L}$ & $F$ & $\mathbf{M}$ & D & $\mathbf{P}$ & $\mathbf{L}$ & $\mathbf{F}$ & $\mathbf{M}$ & D & $\mathbf{P}$ & $\mathbf{L}$ \\
\hline 1 & Alliphis halleri (G. et R. Canestrini, 1881) & Eviphidae & 1 & 1 & - & - & - & - & - & - & - & - & - & - & - & - & - & - & - & - & - & - & - \\
\hline 2 & Amblyseius sp. & Phytoseiidae & 35 & - & - & - & - & - & 2 & - & - & - & - & 27 & 2 & - & - & - & 3 & - & - & 1 & - \\
\hline 3 & Amblyseius tubae Karg, 1970 & Phytoseiidae & 775 & 26 & - & - & - & - & 8 & - & - & - & 1 & 596 & 58 & - & 24 & 1 & 58 & 2 & - & 1 & - \\
\hline 4 & Antennoseius bacatus Athias-Henriot, 1961 & Ascidae & 2 & - & - & - & - & - & - & - & - & - & - & - & - & - & - & - & - & 2 & - & - & - \\
\hline 5 & Antennoseius masoviae Sellnick, 1943 & Ascidae & 1 & - & - & - & - & - & - & - & - & - & - & - & - & - & - & - & 1 & - & - & - & - \\
\hline 6 & Arctoseius brevichelis Karg, 1969 & Ascidae & 1 & - & - & - & - & - & - & - & - & - & - & 1 & - & - & - & - & - & - & - & - & - \\
\hline 7 & Arctoseius insularis (Willmann, 1952) & Ascidae & 45 & - & - & - & - & - & - & - & - & - & - & 8 & - & - & - & - & 32 & 5 & - & - & - \\
\hline 8 & Asca aphidioides (Linneaeus, 1758) & Ascidae & 307 & 88 & - & - & - & - & 100 & - & - & 4 & - & 69 & - & 1 & 4 & - & 36 & 2 & 1 & 2 & - \\
\hline 9 & Asca bicornis (Canestrini et Fanzago, 1887) & Ascidae & 150 & 1 & - & - & - & - & - & - & - & - & - & 75 & 19 & - & 2 & - & 44 & 8 & - & 1 & - \\
\hline 10 & Cheiroseius borealis (Berlese, 1904) & Ascidae & 1 & - & - & - & - & - & - & - & - & - & - & 1 & - & - & - & - & - & - & - & - & - \\
\hline 11 & Dendrolaelaps angulosus (Willmann, 1936) & Digamasellidae & 8 & - & - & - & - & - & - & - & - & - & - & 4 & - & - & - & - & - & - & 4 & - & - \\
\hline 12 & Dendrolaelaps foveolatus (Leitner, 1949) & Digamasellidae & 8 & - & - & - & - & - & - & - & - & - & - & - & - & - & - & - & - & 3 & 5 & - & - \\
\hline 13 & Dendrolaelaps laetus Shcherbak, 1980 & Digamasellidae & 1 & 1 & - & - & - & - & - & - & - & - & - & - & - & - & - & - & - & - & - & - & - \\
\hline 14 & Dendrolaelaps latior (Leitner, 1949) & Digamasellidae & 2 & 1 & - & - & - & - & - & - & - & - & - & 1 & - & - & - & - & - & - & - & - & - \\
\hline 15 & Dendrolaelaps punctatosimilis Hirschmann, 1960 & Digamasellidae & 7 & 2 & - & 2 & - & - & - & - & - & - & - & - & - & 3 & - & - & - & - & - & - & - \\
\hline 16 & Dendrolaelaps rotundus Hirschmann, 1960 & Digamasellidae & 4 & - & - & - & - & - & - & - & - & - & - & - & - & - & - & - & - & 1 & 3 & - & - \\
\hline 17 & Dinychus perforatus Kramer, 1882 & Uropodiade & 1 & 1 & - & - & - & - & - & - & - & - & - & - & - & - & - & - & - & - & - & - & - \\
\hline 18 & Epicriopsis horridus Kramer, 1876 & Ameroseiidae & 13 & 10 & 3 & - & - & - & - & - & - & - & - & - & - & - & - & - & - & - & - & - & - \\
\hline 19 & Eviphis ostrinus (C.L. Koch, 1836) & Eviphidae & 4 & 3 & - & 1 & - & - & - & - & - & - & - & - & - & - & - & - & - & - & - & - & - \\
\hline 20 & Gamasellodes bicolor (Berlese, 1918) & Ascidae & 4 & 1 & - & - & - & - & 3 & - & - & - & - & - & - & - & - & - & - & - & - & - & - \\
\hline 21 & Geholaspis longispinosus (Kramer, 1876) & Macrochelidae & 8 & 6 & - & 1 & 1 & - & - & - & - & - & - & - & - & - & - & - & - & - & - & - & - \\
\hline 22 & Hypoaspis praesternalis Willmann, 1949 & Laelapidae & 15 & - & - & - & - & - & 1 & - & - & - & - & 6 & - & - & - & - & 6 & 2 & - & - & - \\
\hline 23 & Hypoaspis vacua (Michael, 1891) & Laelapidae & 6 & 2 & - & - & - & - & 2 & 1 & 1 & - & - & - & - & - & - & - & - & - & - & - & - \\
\hline 24 & Iphidozercon gibbus (Berlese, 1903) & Ascidae & 18 & 15 & 3 & - & - & - & - & - & - & - & - & - & - & - & - & - & - & - & - & - & - \\
\hline 25 & Laelaspis astronomicus (C.L. Koch, 1839) & Laelapidae & 3 & - & - & - & - & - & 3 & - & - & - & - & - & - & - & - & - & - & - & - & - & - \\
\hline 26 & Lasioseius confusus Evans, 1958 & Ascidae & 1 & - & - & - & - & - & - & 1 & - & - & - & - & - & - & - & - & - & - & - & - & - \\
\hline 27 & Lasioseius muricatus (C.L. Koch, 1839) & Ascidae & 1 & - & - & - & - & - & 1 & - & - & - & - & - & - & - & - & - & - & - & - & - & - \\
\hline 28 & Leioseius elongatus Evans, 1958 & Ascidae & 1 & 1 & - & - & - & - & - & - & - & - & - & - & - & - & - & - & - & - & - & - & - \\
\hline 29 & Leptogamasus anoxygenenellus (Micherdziński, 1969) & Parasitidae & 1 & - & - & - & - & - & 1 & - & - & - & - & - & - & - & - & - & - & - & - & - & - \\
\hline 30 & Leptogamasus belligerens Witaliński, 1973 & Parasitidae & 6 & - & - & - & - & - & 3 & 3 & - & - & - & - & - & - & - & - & - & - & - & - & - \\
\hline 31 & Leptogamasus paroulus (Berlese, 1903) & Parasitidae & 112 & 1 & 1 & - & - & - & 44 & 62 & 1 & - & - & 1 & 1 & - & - & - & 1 & - & - & - & - \\
\hline 32 & Macrocheles montanus (Willmann, 1951) & Macrochelidae & 9 & 5 & - & 2 & 1 & - & - & - & - & 1 & - & - & - & - & - & - & - & - & - & - & - \\
\hline 33 & Nejordensia levis (Oudemans et Voigts, 1904) & Ascidae & 1 & - & - & - & - & - & - & - & - & - & - & 1 & - & - & - & - & - & - & - & - & - \\
\hline 52 & Olodiscus minima Kramer, 1882 & Uropodidae & 287 & 215 & 1 & 64 & 3 & - & - & - & - & - & - & 1 & - & - & - & - & 3 & - & - & - & - \\
\hline 34 & Paragamasus conus (Karg, 1971) & Parasitidae & 12 & 3 & 2 & - & - & - & 3 & - & - & - & - & - & 4 & - & - & - & - & - & - & - & - \\
\hline 35 & Paragamasus jugincola Athias-Henriot, 1967 & Parasitidae & 72 & 39 & 27 & - & - & - & 1 & 5 & - & - & - & - & - & - & - & - & - & - & - & - & - \\
\hline 36 & Paragamasus runcatellus (Berlese, 1903) & Parasitidae & 90 & 51 & 15 & - & - & - & 14 & 7 & - & - & - & 1 & 1 & - & - & - & 1 & - & - & - & - \\
\hline
\end{tabular}


Table A4. Cont.

\begin{tabular}{|c|c|c|c|c|c|c|c|c|c|c|c|c|c|c|c|c|c|c|c|c|c|c|c|}
\hline \multirow{3}{*}{ No. } & \multirow{3}{*}{ Species } & \multirow{3}{*}{ Family } & \multirow{3}{*}{ Total No. of Specimens } & \multicolumn{10}{|c|}{ FH } & \multicolumn{10}{|c|}{ SH } \\
\hline & & & & \multicolumn{5}{|c|}{ Bp } & \multicolumn{5}{|c|}{ Ps } & \multicolumn{5}{|c|}{ Вp } & \multicolumn{5}{|c|}{ Ps } \\
\hline & & & & F & $\mathbf{M}$ & D & $\mathbf{P}$ & $\mathrm{L}$ & $F$ & $\mathbf{M}$ & $\mathbf{D}$ & $\mathbf{P}$ & $\mathrm{L}$ & $\mathrm{F}$ & $\mathbf{M}$ & $\mathbf{D}$ & $\mathbf{P}$ & L & F & M & D & $\mathbf{P}$ & L \\
\hline 37 & Paragamasus sp. & Parasitidae & 71 & - & - & 17 & 7 & 5 & - & - & 21 & 15 & - & - & - & 3 & 1 & - & - & - & - & 2 & - \\
\hline 38 & Parazercon radiatus Berlese, 1910 & Zerconidae & 16 & - & - & - & - & - & 16 & - & - & - & - & - & - & - & - & - & - & - & - & - & - \\
\hline 39 & Pergamasus barbarus (Berlese, 1904) & Parasitidae & 5 & - & - & 4 & 1 & - & - & - & - & - & - & - & - & - & - & - & - & - & - & - & - \\
\hline 40 & Pergamasus brevicornis (Berlese, 1903) & Parasitidae & 5 & 1 & - & - & - & - & 4 & - & - & - & - & - & - & - & - & - & - & - & - & - & - \\
\hline 41 & Pergamasus crassipes (Linneaeus, 1758) & Parasitidae & 62 & 9 & 4 & - & - & - & 2 & 4 & - & - & - & 9 & 4 & - & - & - & 10 & 19 & 1 & - & - \\
\hline 42 & Pergamasus mediocris Berlese, 1904 & Parasitidae & 4 & - & - & - & - & - & 2 & 1 & 1 & - & - & - & - & - & - & - & - & - & - & - & - \\
\hline 43 & Pergamasus septentrionalis (Oudemans, 1902) & Parasitidae & 52 & 39 & 3 & - & 2 & - & - & - & - & - & - & 7 & 1 & - & - & - & - & - & - & - & - \\
\hline 44 & Pergamasus sp. & Parasitidae & 138 & - & - & 20 & 35 & 2 & - & - & 19 & 11 & - & - & - & 8 & 8 & - & - & - & 17 & 18 & - \\
\hline 45 & Prozercon kochi Sellnick, 1943 & Zerconidae & 39 & - & - & - & - & - & 20 & 10 & 7 & 2 & - & - & - & - & - & - & - & - & - & - & - \\
\hline 46 & Prozercon tragardhi (Halbert, 1923) & Zerconidae & 1 & 1 & - & - & - & - & - & - & - & - & - & - & - & - & - & - & - & - & - & - & - \\
\hline 47 & Sejus togatus C.L. Koch, 1836 & Sejoidea & 1 & - & - & - & - & - & - & 1 & - & - & - & - & - & - & - & - & - & - & - & - & - \\
\hline 48 & Trachytes aegrota (C.L. Koch, 1841) & Trachytidae & 710 & 350 & - & 123 & 173 & 27 & 15 & - & 10 & 8 & - & - & - & - & - & - & - & - & 1 & 1 & 2 \\
\hline 49 & Trichouropoda ovalis (C.L. Koch, 1839) & Trematuridae & 14 & 1 & 1 & 6 & - & - & 2 & - & 4 & - & - & - & - & - & - & - & - & - & - & - & - \\
\hline 50 & Typhlodromus pyri Scheuten, 1857 & Phytoseiidae & 1 & - & - & - & - & - & 1 & - & - & - & - & - & - & - & - & - & - & - & - & - & - \\
\hline 51 & Urobovella pulchella (Berlese, 1904) & Urodinychidae & 1 & 1 & - & - & - & - & - & - & - & - & - & - & - & - & - & - & - & - & - & - & - \\
\hline 53 & Veigaia cervus (Kramer, 1876) & Veigaiaiidae & 114 & 37 & - & 3 & 2 & - & 26 & - & 20 & 5 & - & 14 & - & 5 & 2 & - & - & - & - & - & - \\
\hline 54 & Veigaia kochi (Trägarth, 1901) & Veigaiaiidae & 2 & - & - & 1 & 1 & - & - & - & - & - & - & - & - & - & - & - & - & - & - & - & - \\
\hline 55 & Veigaia nemorensis (C.L. Koch, 1839) & Veigaiaiidae & 892 & 432 & - & 223 & 122 & - & 50 & - & 39 & 25 & - & - & - & - & - & - & - & - & - & 1 & - \\
\hline 56 & Veigaia planicola (Berlese, 1892) & Veigaiaiidae & 41 & 27 & - & 9 & 5 & - & - & - & - & - & - & - & - & - & - & - & - & - & - & - & - \\
\hline 57 & Vulgarogamasus kraepelini (Berlese, 1904) & Parasitidae & 2 & 1 & 1 & - & - & - & - & - & - & - & - & - & - & - & - & - & - & - & - & - & - \\
\hline 58 & Zercon peltatus C.L. Koch, 1836 & Zerconidae & 2281 & 509 & 321 & 126 & 68 & 25 & 671 & 52 & 250 & 98 & 144 & 4 & - & 3 & - & - & 5 & 1 & 3 & 1 & - \\
\hline \multirow[t]{4}{*}{59} & Zerconopsis muestairi (Schweizer, 1949) & Ascidae & 1 & - & - & - & - & - & - & - & - & - & - & - & - & - & - & - & 1 & - & - & - & - \\
\hline & \multirow{3}{*}{ In total } & & & F & M & $\mathrm{D}$ & $\mathrm{P}$ & L & F & M & $\mathrm{D}$ & $\mathrm{P}$ & $\mathrm{L}$ & F & M & $\mathrm{D}$ & $\mathrm{P}$ & $\mathrm{L}$ & F & M & $\mathrm{D}$ & $\mathrm{P}$ & $\mathrm{L}$ \\
\hline & & & 6466 & 1881 & 382 & 602 & 421 & 59 & 995 & 147 & 373 & 169 & 145 & 826 & 90 & 23 & 41 & 1 & 201 & 45 & 35 & 28 & 2 \\
\hline & & & & \multicolumn{5}{|c|}{3345} & \multicolumn{5}{|c|}{1829} & \multicolumn{5}{|c|}{981} & \multicolumn{5}{|c|}{311} \\
\hline
\end{tabular}


Table A5. Succession and appearance of the most abundant mites species (Dominance $>1 \%$ ) in Betula pendula (Bp) and Pinus sylvestris (Ps) stands growing in forest habitat (FH) and spoil heap (SH). Shaded cells show the most abundant species within the collection months in each stand type.

\begin{tabular}{|c|c|c|c|c|c|c|c|c|c|c|c|c|}
\hline \multirow{3}{*}{ Habitat Type } & \multirow{3}{*}{ Stand Type } & \multirow{3}{*}{ Species Rank } & \multirow{3}{*}{ Taxon } & \multicolumn{8}{|c|}{ Collection Month (Date) } & \multirow{3}{*}{ Tota } \\
\hline & & & & 3 & 6 & 9 & 12 & 18 & 24 & 30 & 36 & \\
\hline & & & & (10.03.2014) & (09.06.2014) & (10.09.2014) & (10.12.2014) & (10.06.2015) & (09.12.2015) & (09.06.2016) & $(13-14.12 .2016)$ & \\
\hline \multirow{20}{*}{ FH } & \multirow{11}{*}{ Bp } & 1 & Z. peltatus & 280 & 141 & 163 & 111 & 68 & 104 & 109 & 73 & 1049 \\
\hline & & 2 & V. nemorensis & 5 & 10 & 145 & 234 & 106 & 55 & 44 & 178 & 777 \\
\hline & & 3 & T. aegrota & 1 & 139 & 225 & 128 & 32 & 42 & 3 & 103 & 673 \\
\hline & & 4 & O. minima & & 34 & 51 & 31 & 40 & 61 & 19 & 47 & 283 \\
\hline & & 5 & A. aphidioides & 1 & 5 & 9 & & & 21 & 9 & 43 & 88 \\
\hline & & 6 & P. jugincola & & & & 4 & 1 & 22 & 1 & 38 & 66 \\
\hline & & 6 & P. runcatellus & & & 13 & 38 & 5 & 2 & 1 & 7 & 66 \\
\hline & & 7 & Pergamasus sp. & & 2 & 21 & 1 & 26 & & 6 & 1 & 57 \\
\hline & & 8 & P. septentrionalis & & & 11 & 29 & 4 & & & & 44 \\
\hline & & 9 & V.cervus & & & 3 & 23 & 6 & 2 & 3 & 5 & 42 \\
\hline & & 10 & V. planicola & & & & 8 & & 18 & & 15 & 41 \\
\hline & \multirow{10}{*}{ Ps } & 1 & Z. peltatus & 2 & 68 & 339 & 228 & 158 & 202 & 1 & 217 & 1215 \\
\hline & & 2 & V. nemorensis & & & 25 & 6 & 21 & 47 & & 15 & 114 \\
\hline & & 3 & L. parvulus & & 2 & 9 & 16 & 4 & 46 & & 30 & 107 \\
\hline & & 4 & A. aphidioides & & 2 & 72 & 1 & 15 & 3 & & 11 & 104 \\
\hline & & 5 & V. cervus & & & 19 & 3 & 22 & 2 & & 5 & 51 \\
\hline & & 6 & P. kochi & & & 2 & 1 & 10 & 16 & & 10 & 39 \\
\hline & & 7 & Paragamasus sp. & & 2 & 5 & & 27 & 1 & & 1 & 36 \\
\hline & & 8 & T. aegrota & & & 26 & & 4 & 3 & & 0 & 33 \\
\hline & & 9 & Pergamasus sp. & & 3 & 10 & & 14 & 2 & & 1 & 30 \\
\hline \multirow{21}{*}{ SH } & & 10 & P. runcatellus & & & 4 & 2 & 8 & 5 & & 2 & 21 \\
\hline & \multirow{20}{*}{ Bp } & 1 & A. tubae & & & 295 & 153 & 15 & 116 & 6 & 94 & 679 \\
\hline & & 2 & A. bicornis & & & 42 & 36 & 1 & 14 & & 3 & 96 \\
\hline & & 3 & A. aphidioides & & & 73 & 1 & & & & & 74 \\
\hline & & 4 & Amblyseius sp. & & & 9 & 8 & 1 & 2 & 1 & 8 & 29 \\
\hline & & 5 & V. cervus & & & 13 & 2 & 1 & 5 & & & 21 \\
\hline & & 6 & Pergamasus sp. & & & 13 & & 1 & 1 & & 1 & 16 \\
\hline & & 7 & P. crassipes & & & 1 & 4 & 3 & 2 & & 3 & 13 \\
\hline & & 1 & A. tubae & & & 19 & 3 & 1 & 35 & & 3 & 61 \\
\hline & & 2 & A. bicornis & & & 41 & 4 & & 6 & & 2 & 53 \\
\hline & & 3 & A. aphidioides & & & 24 & 1 & 14 & 1 & & 1 & 41 \\
\hline & & 4 & A. insularis & 1 & & 2 & 20 & 2 & 6 & & 6 & 37 \\
\hline & & 5 & Pergamasus sp. & & & 29 & & 4 & & & 2 & 35 \\
\hline & & 6 & P. crassipes & & & 17 & 6 & 2 & 2 & & 3 & 30 \\
\hline & & 7 & Z. peltatus & & & 3 & & 2 & & 5 & & 10 \\
\hline & & 8 & D. foveolatus & & & & & & 1 & & 7 & 8 \\
\hline & & 9 & H. praesternalis & & & 1 & 1 & 4 & & & 2 & 8 \\
\hline & & 10 & Amblyseius sp. & & & 1 & & 1 & & & 2 & 4 \\
\hline & & 11 & D. angulosus & & & & 2 & & & & 2 & 4 \\
\hline & & 12 & D. rotundus & & & & & & 1 & & 3 & 4 \\
\hline & & 13 & T. aegrota & 1 & & 1 & & 2 & & & & 4 \\
\hline
\end{tabular}




\section{References}

1. Berg, B.; McClaugherty, C. Plant Litter, Decomposition, Humus Formation, Carbon Sequestration; Springer: Berlin/Heidelberg, Germany, 2014.

2. Hobbie, S.E. Plant species effects on nutrient cycling: Revisiting litter feedbacks. Trends Ecol. Evol. 2015, 30, 357-363. [CrossRef] [PubMed]

3. Fujii, S.; Takeda, H. Succession of soil microarthropod communities during the aboveground and belowground litter decomposition processes. Soil Biol. Biochem. 2017, 110, 95-102. [CrossRef]

4. Eisenhauer, N.; Antunes, P.M.; Bennett, A.E.; Birkhofer, K.; Bissett, A.; Bowker, M.A.; Caruso, T.; Chen, B.; Coleman, D.C.; de Boer, W.; et al. Priorities for research in soil ecology. Pedobiologia 2017, 63, 1-7. [CrossRef] [PubMed]

5. Chaturvedi, R.K.; Singh, J.S. Restoration of Mine Spoil in a Dry Tropical Region: A Review. Proc. Indian Natl. Sci. Acad. 2017, 83, 789-844. [CrossRef]

6. Sako, A.; Semde, S.; Wenmenga, U. Geochemical evaluation of soil, surface water and groundwater around the Tongon gold mining area, northern Cote d'Ivoire, West Africa. J. Afr. Earth Sci. 2018, 145, 297-316. [CrossRef]

7. Horodecki, P.; Nowiński, M.; Rawlik, K.; Jagodziński, A.M. Rozkład liści drzew w poczatkowych etapach dekompozycji w drzewostanach sosnowych i brzozowych rosnacych na rekultywowanym zwałowisku pokopalnianym i terenach leśnych (Early stages of tree leaves decomposition in pine and birch stands growing on a reclaimed lignite mine spoil heap and forest areas). Studia i Materiaty Centrum Edukacji Przyrodniczo-Leśnej w Rogowie 2015, 17, 262-278.

8. Frouz, J. The effect of soil macrofauna on litter decomposition and soil organic matter accumulation during soil formation in spoil heaps after brown coal mining: A preliminary results. Ekol. Bratisl. 2002, 21, 363-369.

9. Frouz, J. The effect of litter type and macrofauna community on litter decomposition and organic matter accumulation in post-mining sites. Biologia 2008, 63, 249-253. [CrossRef]

10. Frouz, J.; Roubíčková, A.; Heděnec, P.; Tajovský, K. Do soil fauna really hasten litter decomposition? A meta-analysis of enclosure studies. Eur. J. Soil Biol. 2015, 68, 18-24. [CrossRef]

11. Camizuli, E.; Scheifler, R.; Garnier, S.; Monna, F.; Losno, R.; Gourault, C.; Hamm, G.; Lachiche, C.; Delivet, G.; Chateau, C.; et al. Trace metals from historical mining sites and past metallurgical activity remain bioavailable to wildlife today. Sci. Rep. 2018, 8, 3436. [CrossRef] [PubMed]

12. Dunger, W.; Wanner, M.; Hauser, H.; Hohberg, K.; Schulz, H.-J.; Schwalbe, T.; Seifert, B.; Vogel, J.; Voigtländer, K.; Zimdars, B.; et al. Development of soil fauna at mine sites during 46 years after afforestation. Pedobiologia 2001, 45, 243-271. [CrossRef]

13. Russell, D.J.; Hohberg, K.; Elmer, M. Primary colonisation of newly formed soils by actinedid mites. Soil Org. 2010, 82, 237-251.

14. Murvanidze, M.; Mumladze, L.; Arabuli, T.; Kvavadze, E. Oribatid Mite Colonization of Sand and Manganese Tailing Sites. Acarologia 2013, 53, 203-216. [CrossRef]

15. Wang, S.; Ruan, H. Effects of soil mesofauna and microclimate on nitrogen dynamics in leaf litter decomposition along an elevation gradient. Afr. J. Biotechnol. 2011, 10, 6732-6742.

16. Berg, M.P.; Kniese, J.P.; Bedaux, J.J.M.; Verhoef, H.A. Dynamics and stratification of functional groups of micro- and mesoarthropods in the organic layer of a Scots pine forest. Biol. Fertil. Soils 1998, 26, 268-284. [CrossRef]

17. Boczek, J.; Błaszak, C. Roztocze (Acari)_Znaczenie w Życiu i Gospodarce Człowieka; SGGW: Warszawa, Poland, 2005.

18. Koehler, H.H. Predatory mites (Gamasina, Mesostigmata). Agric. Ecosyst. Environ. 1999, 74, 395-410. [CrossRef]

19. Salmane, I.; Brumelis, G. The importance of the moss layer in sustaining biological diversity of Gamasina mites in coniferous forest soil. Pedobiologia 2008, 52, 69-76. [CrossRef]

20. Koehler, H.H. Mesostigmata (Gamasina, Uropodina), efficient predators in agroecosystems. Agric. Ecosyst. Environ. 1997, 62, 105-117. [CrossRef]

21. Reeves, W.K.; Dowling, A.P.G.; Dasch, G.A. Rickettsial agents from parasitic Dermanyssoidea (Acari: Mesostigmata). Exp. Appl. Acarol. 2006, 38, 181-188. [CrossRef] [PubMed] 
22. Wissuwa, J.; Salamon, J.-A.; Frank, T. Effects of habitat age and plant species on predatory mites (Acari, Mesostigmata) in grassy arable fallows in Eastern Austria. Soil Biol. Biochem. 2012, 50, 96-107. [CrossRef] [PubMed]

23. Ruf, A.; Beck, L. The use of predatory soil mites in ecological soil classification and assessment concepts, with perspectives for oribatid mites. Ecotox. Environ. Saf. 2005, 62, 290-299. [CrossRef] [PubMed]

24. VreekenBuijs, M.J.; Brussaard, L. Soil mesofauna dynamics, wheat residue decomposition and nitrogen mineralization in buried litterbags. Biol. Fertil. Soils 1996, 23, 374-381. [CrossRef]

25. Sławska, M. Springtails Collembola, Hexapoda and Mites Acari, Arachnida as indicators of healthy forest soils. Studia i Materiały Centrum Edukacji Przyrodniczo-Leśnej 2007, 9, 208-217.

26. Beaulieu, F.; Weeks, A.R. Free-living mesostigmatic mites in Australia: Their roles in biological control and bioindication. Aust. J. Exp. Agric. 2007, 47, 460-478. [CrossRef]

27. Koehler, H.H. Gamasina in a succession of thirteen years. In Ecology and Evolution of the Acari; Series Entomologica 55; Springer: Dordrecht, The Netherlands, 1999; pp. 531-539.

28. Koehler, H.; Melecis, V. Long-term observations of soil mesofauna. In Long-Term Ecological Research; Muller, F., Baessler, C., Schubert, H., Klotz, S., Eds.; Springer: New York, NY, USA, 2010; ISBN 978-90-481-8781-2.

29. Madej, G. Rozwój Zgrupowań Roztoczy Mesostigmata (Arachnida. Acari) na Nieużytkach Poprzemysłowych; Uniwersytet Śląki: Katowice, Poland, 2004.

30. Madej, G.; Skubała, P. Colonization of a dolomitic dump by mesostigmatid mites (Acari, Mesostigmata). In Acarid Phylogeny and Evolution: Adaptation in Mites and Ticks; Bernini, F., Nannelli, R., Nuzaci, G., DeLillo, E., Eds.; Springer: Dordrecht, The Netherlands, 2002; ISBN 978-1-4020-0465-0.

31. Madej, G.; Stodółka, A. Successional changes and diversity of mesostigmatid mite communities (Acari: Mesostigmata) on reclaimed power plant waste dumps. Ann. Zool. 2008, 58, 267-278. [CrossRef]

32. Pastwik, E.; Skorupski, M.; Piasta, A.; Jagodziński, A.M. Mesostigmata mites of afforested post-industrial habitats on lignite mine spoil heap in Bełchatów-A preliminary study. In Proceedings of the Science for Sustainability-International Scientific Conference for PhD Students, University of West Hungary, Győr, Hungary, 19-20 Marth 2013; Neményi, M., Varga, L., Facskó, F., Lőrincz, I., Eds.; University of West Hungary Press: Sopron, Hungary, 2013; pp. 251-257.

33. Skorupski, M.; Horodecki, P.; Jagodziński, A.M. Roztocze z rzędu Mesostigmata (Arachnida, Acari) na terenach przemysłowych i poprzemysłowych w Polsce. Nauka Przyr. Technol. 2013, 7, 11.

34. Piasta, A.; Skorupski, M.; Horodecki, P.; Jagodziński, A.M. Zgrupowania roztoczy (Acari) pod drzewostanami sosnowymi na terenach leśnych i rekultywowanym zwałowisku zewnętrznym $\mathrm{w}$ Nadleśnictwie Bełchatów (Soil mite communities under Scots pine stands growing on forest sites and reclaimed lignite mine spoil heap in Bełchatów Forest District). Studia i Materiały Centrum Edukacji Przyrodniczo-Leśnej w Rogowie 2015, 17, 279-294.

35. Reich, P.B.; Oleksyn, J.; Modrzynski, J.; Mrozinski, P.; Hobbie, S.E.; Eissenstat, D.M.; Chorover, J.; Chadwick, O.A.; Hale, C.M.; Tjoelker, M.G. Linking litter calcium, earthworms and soil properties: A common garden test with 14 tree species. Ecol. Lett. 2005, 8, 811-818. [CrossRef]

36. Hobbie, S.E.; Reich, P.B.; Oleksyn, J.; Ogdahl, M.; Żytkowiak, R.; Hale, C.; Karolewski, P. Tree species effects on decomposition and forest floor dynamics in a common garden. Ecology 2006, 87, 2288-2297. [CrossRef]

37. Mueller, K.E.; Eisenhauer, N.; Reich, P.B.; Hobbie, S.E.; Chadwick, O.A.; Chorover, J.; Dobies, T.; Hale, C.M.; Jagodziński, A.M.; Kałucka, I.; et al. Light, earthworms, and soil resources as predictors of diversity of 10 soil invertebrate groups across monocultures of 14 tree species. Soil Biol. Biochem. 2016, 92, 184-198. [CrossRef]

38. Skorupski, M. Influence of Selected Tree Species on Forest Ecosystem Biodiversity for the Example of Mesostigmata Mites in a Common-Garden Experiment; Uniwersytet Przyrodniczy w Poznaniu: Poznań, Poland, 2010.

39. Gergocs, V.; Hufnagel, L. The effect of microarthropods on litter decomposition depends on litter quality. Eur. J. Soil Biol. 2016, 75, 24-30. [CrossRef]

40. Gao, M.; Li, J.; Zhang, X. Responses of soil fauna structure and leaf litter decomposition to effective microorganism treatments in Da Hinggan Mountains, China. Chin. Geogr. Sci. 2012, 22, 647-658. [CrossRef]

41. Kaneko, N.; Salamanca, E. Mixed leaf litter effects on decomposition rates and soil microarthropod communities in an oak-pine stand in Japan. Ecol. Res. 1999, 14, 131-138. [CrossRef]

42. Riutta, T.; Slade, E.M.; Bebber, D.P.; Taylor, M.E.; Malhi, Y.; Riordan, P.; Macdonald, D.W.; Morecroft, M.D. Experimental evidence for the interacting effects of forest edge, moisture and soil macrofauna on leaf litter decomposition. Soil Biol. Biochem. 2012, 49, 124-131. [CrossRef] 
43. Slade, E.M.; Riutta, T. Interacting effects of leaf litter species and macrofauna on decomposition in different litter environments. Basic Appl. Ecol. 2012, 13, 423-431. [CrossRef]

44. Singh, K.P.; Singh, P.K.; Tripathi, S.K. Litterfall, litter decomposition and nutrient release patterns in four native tree species raised on coal mine spoil at Singrauli, India. Biol. Fertil. Soil. 1999, 29, 371-378. [CrossRef]

45. Jagodziński, A.M.; Oleksyn, J.; Karolewski, P.; Horodecki, P.; Rawlik, K.; Żytkowiak, R.; Chałupka, W.; Chmura, D.J.; Guzicka, M.; Misiorny, A.; et al. Raport Końcowy z Realizacji Usługi Badawczej pt. "Środowiskowo-Genetyczne Uwarunkowania Produktywności Ekosystemów Leśnych na Gruntach Leśnych $i$ Poprzemysłowych".; Na Podstawie Umowy nr OR/2717/3/11 z dnia 2 Lutego 2011 roku.; Institute of Dendrology, Polish Academy of Sciences: Kórnik, Poland, 2015.

46. Horodecki, P.; Jagodzinski, A.M. Tree species effects on litter decomposition in pure stands on afforested post-mining sites. For. Ecol. Manag. 2017, 406, 1-11. [CrossRef]

47. Hopkins, D.W.; Badalucco, L.; English, L.C.; Meli, S.M.; Chudek, J.A.; Ioppolo, A. Plant litter decomposition and microbial characteristics in volcanic soils (Mt Etna, Sicily) at different stages of development. Biol. Fertil. Soil 2007, 43, 461-469. [CrossRef]

48. Esperschuetz, J.; Zimmermann, C.; Duemig, A.; Welzl, G.; Buegger, F.; Elmer, M.; Munch, J.C.; Schloter, M. Dynamics of microbial communities during decomposition of litter from pioneering plants in initial soil ecosystems. Biogeosciences 2013, 10, 5115-5124. [CrossRef]

49. Jagodziński, A.M.; Wierzcholska, S.; Dyderski, M.K.; Horodecki, P.; Rusińska, A.; Gdula, A.K.; Kasprowicz, M. Tree species effects on bryophyte guilds on a reclaimed post-mining site. Ecol. Eng. 2018, 110, 117-127. [CrossRef]

50. Rawlik, M.; Kasprowicz, M.; Jagodziński, A.M.; Kaźmierowski, C.; Łukowiak, R.; Grzebisz, W. Canopy tree species determine herb layer biomass and species composition on a reclaimed mine spoil heap. Sci. Total Environ. 2018, 635, 1205-1214. [CrossRef] [PubMed]

51. Pietrzykowski, M. Scots pine (Pinus sylvestris L.) ecosystem macronutrients budget on reclaimed mine sites—Stand trees supply and stability. Nat. Sci. 2010, 2, 590-599. [CrossRef]

52. Pietrzykowski, M.; Daniels, W.L. Estimation of carbon sequestration by pine (Pinus sylvestris L.) ecosystems developed on reforested post-mining sites in Poland on differing mine soil substrates. Ecol. Eng. 2014, 73, 209-218. [CrossRef]

53. Jagodziński, A.M.; Dyderski, M.K.; Gdula, A.K.; Rawlik, K.; Kasprowicz, M. Zróżnicowanie flory roślin naczyniowych runa pod drzewostanami powstałymi w wyniku rekultywacji zwałowiska pokopalnianego (Differentiation of the flora of herbaceous layer under tree stands established for the reclamation of the lignite mine spoil heap). Studia i Materiały Centrum Edukacji Przyrodniczo-Leśnej w Rogowie 2015, 17, $249-261$.

54. Horodecki, P.; Nowiński, M.; Jagodziński, A.M. Advantages of mixed tree stands in restoration of upper soil layers on post-mining sites: A five-year leaf litter decomposition experiment. Land Degrad. Dev. 2018. [CrossRef]

55. Kamczyc, J.; Urbanowski, C.; Pers-Kamczyc, E. Mite communities (Acari: Mesostigmata) in young and mature coniferous forests after surface wildfire. Exp. Appl. Acarol. 2017, 72, 145-160. [CrossRef] [PubMed]

56. Skubała, P. Development of oribatid mite communities (Acari, Oribatida) on a mine dump. In Acarid Phylogeny and Evolution: Adaptation in Mites and Ticks; Bernini, F., Nannelli, R., Nuzaci, G., DeLillo, E., Eds.; Springer: Dordrecht, The Netherlands, 2002; ISBN 978-1-4020-0465-0.

57. Ulrich, W.; Zalewski, M. Abundance and co-occurrence patterns of core and satellite species of ground beetles on small lake islands. Oikos 2006, 114, 338-348. [CrossRef]

58. Seniczak, S.; Graczyk, R.; Seniczak, A.; Faleńczyk-Koziróg, K.; Kaczmarek, S.; Marquardt, T. Microhabitat preferences of Oribatida and Mesostigmata (Acari) inhabiting lowland beech forest in Poland and the trophic interactions between these mites. Eur. J. Soil Biol. 2018, 87, 25-32. [CrossRef]

59. Helingerová, M.; Frouz, J.; Šantrůčková, H. Microbial activity in reclaimed and unreclaimed post-mining sites near Sokolov (Czech Republic). Ecol. Eng. 2010, 36, 768-776. [CrossRef]

60. Hagvar, S. From Litter to Humus in a Norwegian Spruce Forest: Long-Term Studies on the Decomposition of Needles and Cones. Forests 2016, 7, 186. [CrossRef]

61. Gonzalez, G.; Seastedt, T.R.; Donato, Z. Earthworms, arthropods and plant litter decomposition in aspen (Populus tremuloides) and lodgepole pine (Pinus contorta) forests in Colorado, USA. Pedobiologia 2003, 47, 863-869. [CrossRef] 
62. Gergocs, V.; Rethati, G.; Hufnagel, L. Litter quality indirectly influences community composition, reproductive mode and trophic structure of oribatid mite communities: A microcosm experiment. Exp. Appl. Acarol. 2015, 67, 335-356. [CrossRef] [PubMed]

63. Karg, W. Synökologische Untersuchungen von Bodenmilben aus forstwirtschaftlich und landwirtschaftlich genutzten Böden. Pedobiologia 1967, 7, 198-214.

64. Jurksiene, G.; Janusauskaite, D.; Armolaitis, K.; Baliuckas, V. Leaf litterfall decomposition of pedunculate (Quercus robur L.) and sessile (Q. petraea [Matt.] Liebl.) oaks and their hybrids and its impact on soil microbiota. Dendrobiology 2017, 78, 51-62. [CrossRef]

65. Osler, G.H.R.; Gauci, C.S.; Abbott, L.K. Limited evidence for short-term succession of microarthropods during early phases of surface litter decomposition. Pedobiologia 2004, 48, 37-49. [CrossRef]

66. Schmidt, R.A. Leaf structures affect predatory mites (Acari: Phytoseiidae) and biological control: A review. Exp. Appl. Acarol. 2014, 62, 1-17. [CrossRef] [PubMed]

67. Maraun, M.; Scheu, S. The structure of oribatid mite communities (Acari, Oribatida): Patterns, mechanisms and implications for future research. Ecography 2000, 23, 374-382. [CrossRef]

68. Erdmann, G.; Scheu, S.; Maraun, M. Regional factors rather than forest type drive the community structure of soil living oribatid mites (Acari, Oribatida). Exp. Appl. Acarol. 2012, 57, 157-169. [CrossRef] [PubMed]

69. Bonari, G.; Migliorini, M.; Landi, M.; Protano, G.; Fanciulli, P.P.; Angiolini, C. Concordance between plant species, oribatid mites and soil in a Mediterranean stone pine forest. Arthropod-Plant Interact. 2017, 11, 61-69. [CrossRef]

70. Karg, W. Acari (Acarina) Milben Parasitiformes (Anactinochaeta), Cohors Gamasina Leach Raubmmilben-Die Tierwelt Deutschlands; VEB Gustav Fischer Ver Lag: Jena, Germany, 1993; Volume 59.

(C) 2018 by the authors. Licensee MDPI, Basel, Switzerland. This article is an open access article distributed under the terms and conditions of the Creative Commons Attribution (CC BY) license (http:/ / creativecommons.org/licenses/by/4.0/). 